\title{
Why Do People Become Modern? A Darwinian Explanation
}

\author{
LESLEY NEWSON \\ PETER J. RiCHERSON
}

MOST MODERN PEOPLE think it is obvious why people become modern. For them, a more interesting and important puzzle is why some people fail to embrace modern ideas. Why do people in traditional societies often seem unable or unwilling to aspire to a better life for themselves and their children? Why do they fail to see the benefits of education, equal rights, democracy, and a rational approach to decisionmaking? What is the glue that makes them adhere to superstition, religion, and obligations to family and tribe even if it means accepting a life of insecurity and poverty?

The "kin influence hypothesis" (Newson et al. 2005) suggests an explanation both for why people become modern and for why modern ideas are often slow to be accepted by a population. The hypothesis is based on the understanding gained by social-psychological research of how cultural norms change. It takes a Darwinian approach to explaining human behavior and recognizes that much of the cultural change associated with modernization is a progressive abandonment of values and norms that encourage people to pursue what evolutionary theorists refer to as "reproductive success."

The kin influence hypothesis proposes that the cascade of cultural changes associated with modernization is the result of the momentous change in the human social environment that occurs early in economic development. For most of human evolutionary history, the norms of all cultures must have prescribed behavior that, on balance, enhanced the genetic fitness of their members. If this were not the case, then, as Lumsden and Wilson (1981) and Alexander (1979) rightly pointed out, evolutionary biologists would be unable to explain how humans evolved the uniquely human capacity for learning and imitation that makes culture possible. Nor could we explain how an African ape came to be the world's dominant organism.

With economic development, however, people begin to abandon the beliefs and values that encourage fitness-enhancing behavior. For example, 
they adopt the idea that smaller families are better even though their increasing wealth makes it easier to raise a large family. Evolutionary biologists, therefore, have the problem of explaining why culture has recently ceased to prescribe fitness-enhancing behavior. Because this change routinely accompanies economic development, it is reasonable to suspect that it is somehow caused by economic development.

The kin influence hypothesis proposes that economic development disrupts the social mechanism that keeps the culture of premodern societies on the track of genetic fitness. In premodern societies, virtually all communities and social networks are kin-based, so most people acquire most of their beliefs, values, and knowledge from their close relatives. Individuals have an "inclusive fitness" ${ }^{2}$ (Hamilton 1964) interest in the reproductive success of their sons, daughters, cousins, nephews, nieces, and grandchildren. This interest has the effect of supporting norms and values that encourage the conversion of resources into offspring rather than "wasting" time and resources on other life goals. However, if social networks become less dense with kin and social interactions mostly occur between people who have no interest in each other's reproductive success, the social support for fitnessenhancing norms weakens. This does not cause a sudden change in culture or behavior, but norms, beliefs, and values increasingly diverge from those that would ensure the active pursuit of genetic fitness.

Newson et al. $(2005,2007)$ show how this idea can work in theory and present empirical evidence in support of the hypothesis. The basic cultural evolutionary mechanism is a "teaching bias" in the terms of Boyd and Richerson (1985). Most people normally espouse values, norms, and behaviors similar to those held by others in their community. Thus, younger people's values, norms, and behaviors substantially reflect those of the previous generation, and culture includes an inertial effect simply by consequence of people learning from each other. However, the same people when communicating with a close relative are slightly more likely to express variants of conventional norms that favor reproductive success, while those communicating with a friend, coworker, or other non-relative are slightly more likely to emphasize other goals. Newson et al. (2007) report role-play experiments that show this effect and also present a theoretical model that indicates how a decrease in the ratio of relatives to non-relatives in a social network can lead to the decline of norms favoring inclusive fitness derived from the biased teaching effect. The rate of decline depends upon the strength of the teaching bias and on the ratio of kin to non-kin in social networks. But, even if the change in network structure is rapid and the teaching bias is quite strong, it is still likely to take several generations for a population to approximate a new equilibrium in norms related to reproduction.

In this article we add to the empirical argument by examining populations that underwent the change in social networks at different times. 
We review evidence that "modernity" is an evolutionary process with considerable cross-cultural predictability and that the leading causal variable is a marked change in social network structure leading to a lower ratio of relatives to non-relatives.

\section{Modernity as a process observed quantitatively}

The European and World Values Surveys, a series of surveys begun in 1981, has produced data that invite social scientists to consider modernity in terms of attitudes and values that can be measured. The findings, based on surveys of over a quarter of a million persons in more than 75 countries, suggest that modernization is a fairly uniform process (Inglehart and Baker 2000; Inglehart and Welzel 2005).

A perception of "multiple modernities" (Eisenstadt 2002) may arise because the values held by people in a modern or modernizing culture continue to reflect some aspects of the population's cultural heritage. But the data show economic development to be associated with a coherent cultural shift away from a traditional value system. The perception of multiple modernities may also arise because this shift is not a discrete event. Once the cultural shift begins, it continues. In 25 years of World Values Survey monitoring, considerable cultural change was detected in economically developed populations as well as in many developing ones (Welzel 2006). This implies that modernity is an ongoing process of change.

Both the starting point and the current state of modernization will differ in historically contingent ways in different societies. It is unhelpful to perceive becoming modern as the adoption of Western values when Western values themselves are continuing to change. Modern Japan is not like modern America in many respects. But then the modern America of 2009 is not like modern America of 1959 or what modern America will be like in 2059 . Nevertheless, the kin influence hypothesis suggests that modernization will have core similarities across cases. People will progressively shift away from a situation where issues associated with marriage, children, and family and community solidarity are uppermost in people's minds to a situation where issues associated with education, professional success, personal comfort, acquisition of property, and the like are uppermost.

The suggestion that there are "traditional values" implies that premodern cultures, although diverse in many respects, share certain values that are different from those of "economically developed" cultures. This is consistent with the view of Inkeles and Smith (1974), who demonstrated that individuals within modernizing populations begin to abandon a suite of "traditional attitudes," such as the desire for a large family and passivity in the face of obligations to family and elites, and replace them with "modern attitudes," such as political activism, a desire to better one's self, and a recognition of the need to control family size. 
The observation that members of traditional and modern communities differ sharply in their values and attitudes goes back at least to Tönnies's Gemeinschaft-Gesellschaft distinction (Tönnies 1957 [1887]). The idea of "traditional values" shared by premodern cultures is also consistent with the observations of sociologists and anthropologists who have searched for similarities rather than differences between cultures (e.g., Murdock 1967; Brown 1991) and of human behavioral ecologists who have analyzed the norms and practices of a wide range of small-scale societies from a Darwinian perspective (e.g., Chagnon 1988; Hill and Hurtado 1996; Borgerhoff-Mulder 1988; Cronk 1989; Irons 1979; Wang et al. 1995; and reviews by Cronk 1991 and Low 1993, 1999, 2000).

\section{Environmental and evolutionary explanations of modernization}

Inkeles and Smith (1974) suggested that exposure to modern institutions, such as schools and businesses, causes people to abandon "traditional attitudes" in favor of attitudes that are more appropriate to a modern social and economic environment. But the idea that modern attitudes are spread by diffusion to new populations does not explain why these attitudes emerged in the first place in European populations in the eighteenth and nineteenth centuries. Nor does it explain why the process of cultural change continues in populations after they have "become modern." Explanations of cultural change can be "environmental" or "evolutionary." Both kinds of explanation have been offered to describe modernization.

Environmental explanations are synchronic, suggesting that behavioral changes are adaptations by individuals to contemporaneous changes in their social or economic circumstances. When explaining behavioral change in terms of rational choice or genetically evolved psychological mechanisms, scholars are offering environmental explanations. The environment of an economically developing society is continuously changing through the introduction of new technology, changes in the law, business practices, and political systems, increasing wealth, improving health, widening communication, intergroup conflict, migration, and many other changing factors. All of these changes are seen to influence the behavior of members of a population. For example, specific modern inventions are often credited with causing people to decide to change their reproductive behavior; birth control technology is accepted by many social scientists and members of the public as a cause of a change in sexual mores.

Evolutionary explanations are diachronic, suggesting that while contemporaneous events may be driving marginal changes, a substantial amount of social change is the result of processes set in motion by changes in the distant past. Explanations in terms of natural selection are the classic 
evolutionary explanations. A descendent population differs only slightly from its immediate ancestors even though one species may eventually be transformed into another if selection acts in a consistent direction for many generations. Evolutionary processes play out over an extended period of time and will continue until a new equilibrium is reached. The process of change and its future trajectory can be better understood, therefore, by using models that represent the whole trajectory of past change. But the historical trigger of the evolutionary process is not readily linked with the present-day consequences, so the cause of change and the mechanism of causation may be obscure. Also, when changes are the result of an evolutionary process, attempts to influence their speed and direction are unlikely to be effective unless they are directed at the underlying instability that is driving the change process.

Evolutionary processes behave in this way because inherited elements generate lags in a population's response to change. This has been closely studied in biological ecosystems. When a population of organisms experiences a change in the natural environment, genes are the inherited elements that create lags. Each new generation inherits the genes of its parents and therefore resembles antecedents that were adapted to conditions that existed before the change. But as Darwin (1859) pointed out, a change in the environment generates new selective pressures that work over many generations, causing changes in the living things that inhabit the environment.

In the case we examine here, it is culture, not genes, that creates the lag. During the early part of their lives, humans acquire beliefs, values, skills, customs, and other cultural information by imitating and learning from members of previous generations. As they grow older and more experienced, they may modify cultural information they have acquired to make it more relevant to their current circumstances. Because such modifications can then be transmitted via social learning to others in the population, individual decisionmaking is a direct and powerful evolutionary force in cultural evolution. For this reason, we expect cultural evolution to be faster than genetic evolution (Boyd and Richerson 1985). Nevertheless, populations tend to maintain many cultural characteristics that were created as an adaptation to earlier circumstances. The cultural change known as modernization is a multi-generation diachronic process that is apparently ongoing today even in societies that industrialized several generations ago. To understand an evolutionary process and to predict how it is likely to proceed, we must identify what is driving it.

A scholar presenting an evolutionary explanation for behavioral change may argue that the invention of birth control cannot be considered the cause of the change in sexual mores because history shows that the demand for contraception emerged before the technology was invented to meet that demand. Once the technology existed, however, sexual behavior changed 
in response. Causation is therefore difficult to ascribe, and both can be seen as part of a cultural evolutionary process.

Most current evolutionary explanations for modernization assume that the change processes were triggered by liberation from constraints that existed in the past. Many components of modernization have been treated as causally independent triggers. The introduction of schools, for example, could have allowed people to see new possibilities. The growth of scientific knowledge encourages people to question religious dogma. Technology and division of labor reduced drudgery. Wage labor alleviated poverty and loosened the social controls imposed by family, church, and community. More liberal political systems gave people greater freedom of choice. Improved communication gave people information that allowed them to make better choices (e.g., Lesthaeghe 1983; Inglehart and Welzel 2005). The plausibility of these proposals notwithstanding, we will try to show that such particulars of modernization are part of a pattern that can be explained more economically in terms of an evolutionary process that generates all of them.

"Liberation from constraints" hypotheses do not specify the directions in which culture will evolve. Earlier social theorists noted a gradual secularization and the replacement of superstition with rationality and science (e.g., Weber 2001 [1930], 1951). But as cultural change progressed, it became clear that the changes could not be attributed to people making rational choices. Even Becker (1960), who has argued that children can be viewed as consumer items, recognized that rationality and economic circumstances cannot completely account for why a person may prefer a baby to a new car. Research in social psychology has shown that individuals economize on cognitive effort when faced with choices. People sometimes "make up their mind" by taking the time to rationally evaluate the available evidence. But they often form opinions by rapidly observing superficial cues about the choices available, such as which choice appears to be most popular (e.g., Hovland et al. 1953; Petty and Cacioppo 1986).

Liberation from constraints does explain how modern people have obtained the time and resources to follow a plethora of odd hobbies (Wolfe 1965), but not why they are motivated to do so. It therefore does not provide the basis for an evolutionary approach that can explain cultural change or cultural diversity or predict how culture will change over time. It gives no reason to believe that the direction of cultural change will be anything but random. Because the data we review below show that modernity represents a fairly tight and predictable pattern of change that has many crosscultural similarities, we consider it likely that another process is driving the change.

The lack of explanatory power of the evolutionary "liberation from constraints" approach may explain why social scientists have mostly used synchronic approaches when attempting to explain and predict social change. 
This involves monitoring changes in the environment and considering how human psychology might adapt to those changes. These approaches also have weaknesses, however. Modern and modernizing societies experience many environmental and cultural changes. Reasons why one change may cause another readily suggest themselves, and correlations between variables provide empirical evidence to support suggestions. But there is often a high degree of collinearity between the variables, and the direction of causation is often questionable. For example, as a population modernizes, wealth tends to increase, family size decreases, and women become better educated and more likely to work outside the home. This series of changes supports the suggestion that the alleviation of poverty causes people to have fewer children. But it also supports the suggestion that educating women and putting them to work outside the home causes wealth to increase. In part, this is a simple artifact of national income statistics; the unpaid work of women in the household is not counted in the economic statistics.

Much effort has been spent investigating environmental variables such as socioeconomic factors and examining relationships between them and measures of opinion and behavior. This work has not, however, led to the development of models that reliably explain cultural differences or accurately predict cultural change. Adding formal diachronic hypotheses to the candidate explanations offers new causal explanations that may succeed where synchronic explanations have not. Synchronic explanations are not designed to be sensitive to causal arrows that point downward through time. Our argument here is that the evolutionary process has created the collinearity that bedevils purely synchronic explanations of modern behavior.

\section{An evolutionary explanation informed by Darwinian theory}

The kin influence hypothesis suggests an evolutionary explanation for the cultural change accompanying modernity that is more specific than "liberation from constraint" hypotheses. It specifies a single historic change as the trigger for the evolutionary process and describes a mechanism that would drive culture to change in certain directions. Thus the hypothesis provides the basis of predictions about the direction of cultural change. Tests of these predictions provide a way of assessing the importance of the proposed mechanism. ${ }^{3}$ The hypothesis is that the switch from largely kin-based to largely non-kin-based social networks generates a strong cultural evolutionary force that is common to almost all modernizing societies.

Thus the kin influence hypothesis suggests an explanation for a pattern of progressive cultural change that is characteristic of modernity-a pattern that has not been addressed by other social change theories. Although exceptions are sometimes found (Coale and Watkins 1986; Edgerton 1992), the 
norms and values characteristic of traditional societies encourage members to behave in ways that are close to optimal for maximizing genetic fitness (Chagnon 1988; Hill and Hurtado 1996, Borgerhoff-Mulder 1988; Cronk 1989; Irons 1979; Wang et al. 1995; and reviews by Cronk 1991 and Low $1993,1999,2000)$. This is not to suggest that the reproductive norms of all of these societies were or are the same. Only the outcome is the same: the maximization of genetic fitness.

It is a general biological maxim that living organisms compete not for their own survival but for the survival of the information in their genes (Hamilton 1964). The genetic fitness of an individual is determined by the number of copies of its genes that are present in future generations. We are descended from (and carry the genes of) individuals who managed to survive and to raise children who themselves managed to raise children and so on. Deciding not to make the sacrifices necessary to raise children might have made our ancestors live longer and easier lives. But our ancestors did make these sacrifices and that is why we exist.

The norms of traditional societies do not encourage people simply to produce offspring. They encourage the successful rearing of children in circumstances that are often difficult and they also encourage cooperation between relatives (Hrdy 1999, 2007). Close relatives share many of the same genes, so helping relatives enhances an individual's "inclusive fitness" (Hamilton 1964). The marriage, kinship, and gender role norms of traditional societies encourage cooperation between relatives, and they regulate the mate choice of members entering their reproductive years (Apostolou 2007). Parents and other kin arrange matches to link families in a commitment to cooperate in raising the next generation. Norms also influence the timing of births so that adequate resources are likely to be available to raise offspring (e.g., Mace 1998; Bledsoe et al. 1994). Some people in traditional societies may be encouraged to postpone or forgo having children themselves and instead devote their time to caring for their relatives (Low 1999). Many societies have norms and beliefs that encourage the abandonment of babies who show signs of birth or genetic defects or who fail to thrive (Hrdy 1999). From a biological perspective, therefore, the reproductive norms of traditional societies do not encourage mindless procreation but do encourage the efficient use of resources to produce the maximum number of surviving offspring in each generation.

Traditional norms and values limit people's aspirations by keeping them focused on fundamental biological goals. They do not permit the level of comfort valued and seen as necessary by people in modern societies because excess resources are invested in the production of children. This level of investment creates more copies of their genes and also propagates their culture. At the same time it creates more mouths to feed and minds to educate.

Modern cultures have beliefs, values, and norms that make it much easier for their members to win the competition to maximize the number of 
years that they survive. But they do so by encouraging them to retire from the biological competition that maximizes the numbers of copies of their genes that survive beyond their death. Put another way, success as defined by the culture and genetic success become decoupled when societies modernize (Richerson and Boyd 1984).

Darwinian theory, therefore, suggests that explaining why people begin to abandon traditional values is more difficult than explaining why people are slow to adopt behaviors likely to increase their comfort and security at the expense of their biological fitness. Economic development brings greater resources, which allows more children to be raised; so unvarnished Darwinian theory predicts that the response will be to produce more offspring, not fewer (Richerson and Boyd 1984; Vining 1986). Indeed, when a society begins to develop, population rapidly increases. So why do values change such that people begin to want fewer children? Favoring relatives is likely to enhance an individual's fitness by improving his or her reproductive success. Tribalism supports long-standing collective strategies that usually enhance the fitness of tribal members (Richerson and Boyd 1999). So why does culture change so that nepotism or "amoral familism" begins to be thought of as corrupt? Why do tribal identities begin to weaken with economic development?

In the populations that were the first to modernize, attitudes toward reproduction have continued to evolve, and current norms about gender roles, sexual behavior, and parenting in these societies are even more difficult to explain in Darwinian terms. The process of change was most closely monitored in the population of the United States. In the early twentieth century, marriage became increasingly regarded as the union of two people who love and are attracted to each other, rather than a partnership for the purpose of creating a family (Ogburn and Nimkoff 1955; Buss et al. 2001). Since the 1970s, marriage or marriage-like relationships between people of the same sex have become increasingly accepted (Avery et al. 2007). Meanwhile, families have become less stable, with parents more inclined to divorce or to cohabit without marrying (Bumpass and Lu 2000; Espenshade 1979). It has become increasingly common for women to postpone having children, and in many cases this results in their having no children or fewer children than they would like (Bongaarts 2001).

In the latter part of the twentieth century, the concept of gender empowerment emerged in the populations that had been the first to modernize. It became regarded as a virtue for societies to encourage women to do the same work as men and for women to seek that work (Thornton et al. 1983). Yet a sexual division of labor is much more advantageous from the point of view of maximizing fitness. Biology constrains men and women to perform different reproductive roles. Women gestate the young and produce milk to feed them, so maternal care is more vital for infant survival than is paternal care (Low 2000). The fitness of both men and women is enhanced if women are able to provide necessary childcare. Studies of a number of 
traditional foraging cultures have shown that work performed by women consists largely of tasks that can be done while they care for young children (Brown 1970; Hurtado et al. 1992; Hill and Kaplan 1988). Activities of human males are not constrained by carrying infants to term and nursing them. In traditional societies men typically help to provision women and children through activities like hunting, herding, farming, and wage labor. From the evolutionary biologist's point of view, gender empowerment, which encourages women to pursue the same activities as men, prevents couples from obtaining the fitness advantages inherent in the traditional gender-based division of labor.

In summary, many of the cultural changes that occur in modern or modernizing countries reflect a dismantling of the norms, beliefs, and values that in traditional societies encourage behavior consistent with the pursuit of long-term genetic fitness.

\section{An enduring change in social structure}

The kin influence hypothesis suggests that the increasing abandonment of biological goals is part of a cultural evolutionary process triggered by the profound change in social structure that accompanies economic development (Newson et al. 2005). In premodern and prehistoric human societies and even in ancestral hominid populations, individuals lived as part of a relatively closed social group in which frequent social interaction took place between kin (Foley 1996). In traditional communities children work, play, and are educated among their family. When they leave their natal community, it is usually to live among other families. Some premodern societies had traditions of young adults temporarily joining an unrelated or distantly related family as an employee (Hajnal 1982; Smith 1981). But a more common tradition was for young adults to leave their natal community when they married and become part of the community to which their spouse's family belonged. Some historians have argued that kinship ties may have been weak in premodern northwest Europe, where the nuclear family household has a long history. Historical evidence suggests, however, that even if kin did not live under the same roof, they were in frequent contact and the sentiments and responsibilities of kinship were strong (Cressy 1986).

When a society begins to undergo economic development, new kinds of social networks start to form. Before a society begins to develop, the family is the main unit of production. Apart from those living in cities, where a relatively small proportion of the population lived prior to economic development, people perform work and acquire resources as part of the family (Davis 1997 [1937]). As industrialization progresses, new kinds of organizations for production and trade provide people with new means of making their living. Mining, manufacturing, shipping, and retail trade provide labor opportunities in large firms that draw labor from long distances. People join 
these organizations as individuals, often leaving their extended family to live in nuclear families in industrial and commercial centers. Thus, congregations of unrelated individuals form, and non-kin-based social networks emerge. Industrial modes of transportation make long-distance migration easier. Communication technology, from books and newspapers to the Internet, allows information exchange by people who have never met. By taking advantage of emerging opportunities and new sources of information, individuals increasingly interact with people who are not family members and who have been raised in different local traditions.

That economic development brings these changes to the structure of society has been observed by many social change theorists, and the possible consequences of such changes have been widely discussed. Weber, Durkheim, Tönnies, and other nineteenth- and early-twentieth-century social theorists also considered changes in the nature of community to be linked to the social change associated with modernization. More recently, scholars have linked the change in social networks to a particular modernizing change that is symptomatic of a reduced motivation to maximize fitness: the adoption of family limitation. Davis (1997 [1937]) proposed the diminishing role of the family as a cause of fertility decline. Zelinsky (1971) more formally documented the phenomenon, showing that higher rates of social and spatial mobility occur with modernization and closely parallel the demographic transition. Watkins (1990) suggested that the fertility decline in Europe is linked to the widening of communities, a suggestion supported by research on populations currently experiencing fertility decline. An association between change in social networks and the adoption of family limitation has been widely reported. In developing countries, women who attend market, live near a bus route, belong to a club, have attended school, or have seen a movie have been found to have more modern reproductive behavior. They have fewer children and are more likely to be using birth control (e.g., Kohler 2001; Axinn and Barber 2001; Axinn and Yabiku 2001; Barber et al. 2002; Valente et al. 1997; Behrman et al. 2002; Watkins and Danzi 1995).

In most previous analyses, however, this change in the social environment has been treated as a synchronic environmental variable. Scholars have agreed that it is likely to cause cultural change, but they have only considered changes observed at the same time or immediately afterward. They have not considered that an enduring change in the structure of communities might have an enduring capacity to cause cultural change and thus set in train a process of change that plays out as an evolutionary process, rather than merely causing changes that take place over a short time interval.

\section{The evolution of cultural norms}

Durkheim's view (1984 [1893]) that modern societies lack the solidarity that comes from a "collective conscience" is disputed by both common experience 
and research into the social processes characteristic of humans. Complete strangers who are socialized into new traditions can perceive themselves to be part of a cohesive group and share a common identity. Through social interaction, members of a group generate and modify norms, values, and beliefs that coordinate group behavior and mediate interaction between its members (Postmes et al. 2000; Postmes et al. 2001; Turner 1982; Turner et al. 1987). Evolved human social psychology appears to include a facility for forming cooperative groups (Richerson and Boyd 2001).

The change in the composition of social networks that occurs when societies modernize does not create societies that have no norms (what Durkheim called "anomie"), but it is likely to cause different norms, values, and beliefs to emerge. In traditional societies, a large proportion of the social interaction is between relatives, who have an interest in each other's reproduction. Babies born in the community will have many community members as relatives. A healthy baby promises to be an ally and a companion in furthering family interests, but also a new responsibility for the family. During social interaction between kin, therefore, both parties have an interest in encouraging behavior consistent with the competent rearing of children, and this is likely to influence the information they communicate.

As mentioned above, role-play experiments support the suggestion that people are more inclined to encourage effective reproduction when talking to their kin than when talking to their friends (Newson et al. 2007). Female participants playing the role of a mother advising her hypothetical daughter prefer behavioral choices that are more consistent with successful reproduction than do participants playing the role of a woman advising a younger friend. A decline in the proportion of interaction with kin versus interaction with non-kin is, therefore, likely to change social norms. A well-established body of social psychological research has shown that social norms evolve as a result of changes in the information and feedback passing between members of a social network (Sherif 1935; Festinger et al. 1950; Sherif and Murphy 1936; Turner 1991; Turner et al. 1987)

In the role-play experiments, however, the participants' choices and advice largely reflected the reproductive norms of the contemporary Western society to which they belonged. Mother-role participants were more encouraging of successful reproduction than women playing the role of friend, but only marginally so. Newson et al. (2007) use a formal mathematical model to show that such a weak kin bias is sufficient to support norms for high fertility when kin dominate social networks but is not strong enough to prevent their relaxation when non-kin dominate social networks. Thus, the decline in family size and many other signatures of modernity do not follow immediately upon the change from kin-dense to kin-sparse social networks. The transition to small families transpires diachronically (evolves) over several generations. 
We argue here that the broader process of modernization is likewise a historical process set in motion by the revolution in social network structure. The young Europeans who came together in the eighteenth and nineteenth centuries to serve in the armies, to work in factories and mines, or to emigrate were raised in traditional communities and brought with them the pronatalist reproductive norms, values, and expectations of these communities. Like the contemporary participants in the role-play experiments mentioned above, their choices and advice would have reflected their upbringing. Nevertheless, the information passing between non-kin was likely to have been, on balance, less consistent with effective reproduction than information passing between kin.

As noted above, models show that a relatively weak cultural "teaching bias," whereby kin depart from prevailing norms in a slightly pronatalist fashion and non-kin in slightly antinatalist fashion, will eventually lead to multi-generation demographic transitions such as those experienced by European populations (Boyd and Richerson 1985; Newson et al. 2007; Richerson and Boyd 1984). In countries at the earliest stage of modernization, people will continue to behave largely according to the beliefs and values of kin-based communities. But the model predicts that once social networks widen, norms will increasingly diverge from those that encourage the pursuit of genetic fitness. Generation-by-generation, individuals will see less value in the efficient production of children.

In countries that began to experience rapid fertility decline in the second half of the twentieth century, the slightly less pronatalist influence from non-kin was augmented by exposure to mass media and frank antinatalist messages from governments and nongovernmental organizations encouraging family planning (Bongaarts and Watkins 1996). Not surprisingly, these transitions have occurred at an earlier stage of economic development and have proceeded more swiftly than the previous transitions of European populations.

\section{Modernization and the relaxation of social norms promoting genetic fitness}

The onset of the fertility decline is an early and easily detected sign that the dismantling of pronatalist traditional norms has begun. Even though economic development increases access to resources, fertility declines because people cease to efficiently convert resources into offspring. But there is no reason to believe that the abandonment of the pursuit of fitness will be limited to the emergence of a preference for smaller families. Weakening of the social rewards and sanctions that maintain effective reproduction and cooperation between kin will set in train a number of other cultural changes (see Figure 1): 
FIGURE 1 In traditional communities, a high frequency of kin interactions acts as a social "force" that supports cultural norms prescribing behavior consistent with achieving genetic fitness. With modernization, people spend more time in non-kin-based social networks, the social force is weaker, and norms progressively diverge from those necessary to maintain optimal reproductive behavior

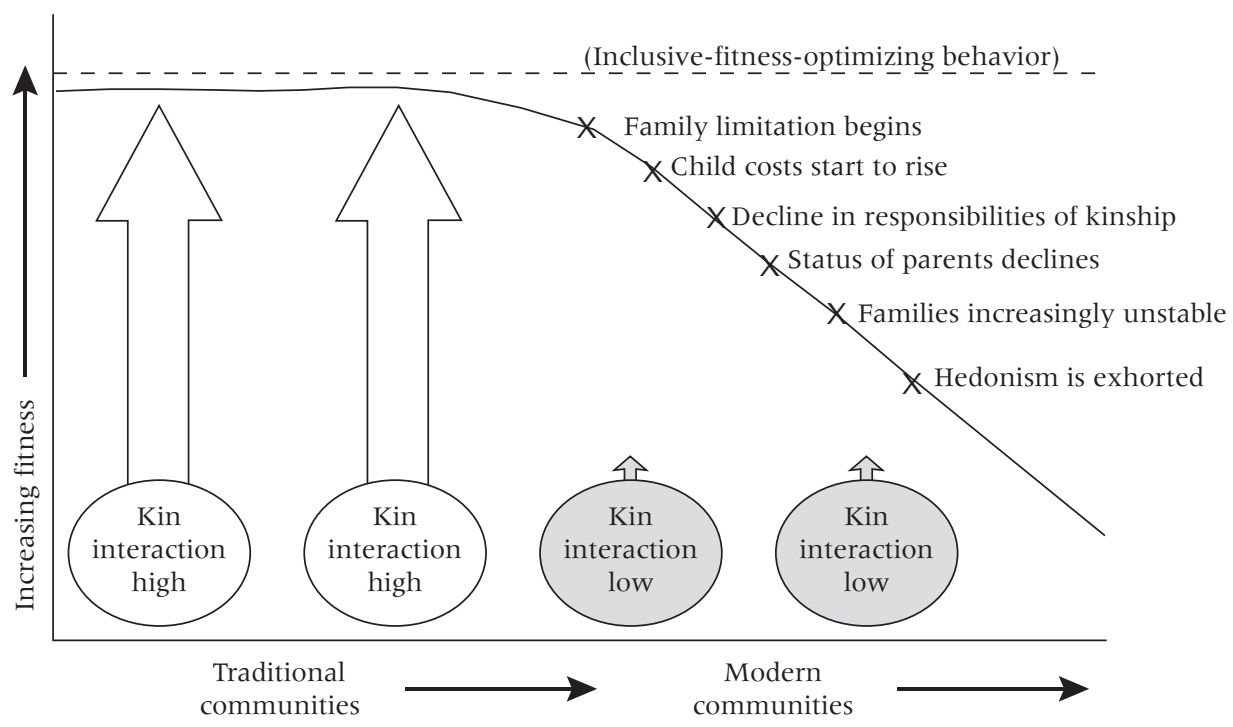

1) Decline in social pressure to respect family elders and cooperate with relatives will cause people increasingly to seek social rewards from non-family members and see non-family members as social models.

-People of all ages will identify with groups that are not based on kinship but whose members share other common interests. Goals linked with these common interests will therefore become increasingly important relative to goals related to the family.

-Nepotism and tribalism will decline as loyalty to family and longstanding family alliances diminishes and loyalty to other institutions, such as an employer, a political party, or the state, increases.

-Non-family institutions will increasingly assume responsibilities that were previously undertaken by the family, such as educating the young and caring for the sick and elderly.

2) Decline in the social rewards associated with getting married and becoming a parent will cause people to replace these goals with those that attract greater social rewards.

-Getting married will become increasingly unpopular.

-The criteria for being considered a "good parent" will become increasingly ill-defined but at the same time more difficult to satisfy. Children will become endowed with expensive needs unrelated to their own reproductive success but necessary for their social success in the modernizing world. 
-Women will feel increasingly dissatisfied with a life devoted to caring for a home and family and will want to do work that they perceive to be more prestigious or rewarding.

3) Decline in the social rewards associated with behavior that supports the family institution will cause family stability to decline.

-Young adults will increasingly want, and be increasingly allowed, to choose a marriage partner whom they find attractive rather than one who will be favored by their relatives and who is likely to be an effective partner in producing and raising the next generation.

-Children will be less willing to cooperate with older family members to achieve goals they believe worthy and will increasingly seek the approval of their friends.

-Couples will be less and less inclined to make personal sacrifices to maintain a stable home for their children.

4) Relaxation of the social sanctions against behavior that disrupts the family will make the disruption of families more common.

- Sexual promiscuity and adultery will increase, resulting in higher levels of sexually transmitted diseases, accidental pregnancy, and family conflict.

—Divorce will become easier to obtain and more common.

These cultural changes have been and continue to be experienced by the populations of European descent that were the first to modernize. Lesthaeghe (1983) has referred to many of the changes in reproductive norms experienced by Europeans in the latter part of the twentieth century as a "second demographic transition." The kin influence hypothesis proposes that the first and second transitions are in fact not distinct but are part of the same evolutionary process.

As the evolution of norms and values continues, some members of the population resist new changes while others argue that they are merely a progression from aspects of culture that are already widely accepted. For example, traditional societies perceive marriage as a reproductive partnership that involves the families of the marriage partners. With modernization, marriage is increasingly seen as a union of two people who love and are attracted to each other. This view of marriage is now uncontroversial in Western cultures. Nevertheless, many Westerners still feel uncomfortable with the idea that people of the same sex should marry if they love and are attracted to each other.

With respect to virtually all aspects of reproduction (e.g., sexual behavior, parenting, gender roles), large cultural differences exist between the countries that began to modernize in the eighteenth and nineteenth centuries and those that began to modernize in the middle and latter part of the twentieth century. But if modernization is an evolutionary process that causes cultural norms, beliefs, and values to diverge increasingly from those that encourage behavior likely to enhance genetic fitness, then similar 
changes in reproductive norms will eventually be experienced by all populations once economic development has begun. Modernization should be a reasonably tight complex of co-evolving cultural changes in which different modernizing societies evolve in a parallel fashion.

The kin influence hypothesis therefore predicts that a substantial part of cross-cultural variation between norms, values, and beliefs that affect the pursuit of fitness will be explained by the amount of time that has passed since the social networks in the population started to widen and become less kin-based.

\section{Modernization and the rise of secularism}

The widening of social networks is also a plausible trigger for the evolution of culture from values and beliefs supported by tradition, religion, and superstition toward values and beliefs supported by rational discussion and scientific investigation. As Durkheim (1984 [1893]) pointed out, people within small, relatively isolated traditional communities rely on shared traditions and experiences to negotiate the shared norms, values, and beliefs that mediate their social interactions. Once economic development begins, it is increasingly common for people to live within communities whose members have been raised in a variety of local traditions. They therefore need to find other grounds on which to develop social conventions.

In such groups, rational argument and evaluating evidence would have been useful tools for taking account of novel circumstances and contributing to social negotiations. Also, when people work with industrial technology and engage in trade, prestige is afforded to those adept in science and rational discourse. As formal schooling spreads, children are exposed to teachers schooled in science and rationality. At work, ordinary people are exposed to engineers and managers with more advanced education and a strong commitment to rationality and science. In contrast, prestige figures in premodern Europe were more likely to be experienced older men and women who headed large families or religious figures who had an interest in maintaining traditional local values.

If the spread of rationalism and secularism is also the result of the widening of social networks, changes in the religious beliefs of a population, such as a belief in God and life after death, will parallel the change in norms and beliefs that affect the pursuit of fitness. Religiosity and the prevalence of traditional superstitious beliefs will become less prevalent once social networks widen, and as time passes these beliefs will be replaced with more secular and rationally based beliefs.

Thus, the kin influence hypothesis also predicts that a substantial part of the cross-cultural variation in the extent to which people's beliefs are influenced by religious faith will be largely explained by the amount of time 
that has passed since the social networks in the population began to widen and become less kin-based.

\section{Explaining anomalies of modernization}

A successful explanation for the patterns of modernity must explain not only the main trends in cultural change but also the exceptions, the behavior of people in societies that have taken a different cultural path.

The Anabaptist communities in rural parts of the United States and Canada are demographic anomalies. The Amish, Hutterites, and some Mennonite sects maintain the attitudes and behaviors characteristic of premodern societies. They are not unthinking rigid traditionalists, however. They partake of modern ideas and products that do not threaten their way of life, such as modern medicine. Members of the community participate extensively in the modern economy, typically as commercial farmers, and this allows them to enjoy the financial security and health experienced by people living in a modern society. On the other hand, they remain socially separated from people outside their communities; their religious principles advise that they live in closed kin-based communities (Greksa 2002; Kraybill and Olshan 1994).

If environmental variables such as financial and health security cause people to choose to have fewer children, then members of Anabaptist communities should have small families like people in other communities in North America. The kin influence hypothesis, however, predicts that their closed kin-based communities will maintain the pronatalist norms characteristic of traditional communities even if they otherwise participate in economic modernization. The prediction of the hypothesis closely fits the observed behavior of people in these communities, where families of seven or more children are common, children leave school in their early teens to help their parents, and the work of men and woman conforms to traditional gender roles.

Note that "pronatalist beliefs" by themselves are not reliably associated with high fertility. In the United States, Catholics and conservative Protestants espouse pronatal, pro-family, and anti-abortion values. But their fertility actually converged to the US mean several decades ago (Hout et al. 2001). The cultural isolation and kin-rich social networks of the strict Anabaptists seem to be necessary to retain high fertility in a modern context.

Another apparent anomaly is the low fertility of large parts of the French population in the early nineteenth century. If one considers environmental variables associated with economic development to be the trigger for the adoption of family limitation, fertility should have declined first in England. England industrialized earlier than France, and by the early nineteenth century much more of its population was employed in industry. Yet fertility remained high in the English population until the end of the nine- 
teenth century, while the fertility of France's rural agricultural population began to decline in the 1820s (Coale and Watkins 1986). The kin influence hypothesis explains this apparent anomaly by providing another explanation for the early fertility decline in France.

Industrialization and socioeconomic development are one cause of the widening of social networks. But other kinds of social change will also disrupt the family-based social structure characteristic of premodern societies. In the late eighteenth century, France experienced a decade of revolution that restructured rural as well as urban communities. On the other hand, during the early stages of the industrial revolution in England, village social structure may have remained relatively intact. In the Severn Gorge region, where the English industrial boom was underway by the late eighteenth century, mines and factories sprang up in the countryside near natural resources and attracted local labor. Families often worked as teams, developing the skills that allowed them to specialize in a particular kind of industrial work and teach those skills to their children (Trinder 2000). Early English economic modernization seems to have allowed kin-based social networks to endure for a generation or two longer did than the French social revolution. The kin influence hypothesis suggests that this may be why fertility declined first in France.

The hypothesis also provides an explanation for the low fertility experienced by many urban populations (Livi-Bacci 1986) long before the modern demographic transition. Cities attract migrants and visitors from many regions, hence wide social networks are often inevitable even in premodern times. There is evidence that fertility was low even in Ancient Rome (Parkin 1992). Perhaps the population of premodern cities was typically maintained solely by immigration from the surrounding countryside, where fertility was higher (Knauft 1987).

Thus, the kin influence hypothesis explains demographic behavior that is not explained by hypotheses that ascribe causation to environmental variables.

\section{Testing predictions of the kin influence hypothesis}

Earlier we mentioned two predictions of the kin influence hypothesis:

-A substantial part of cross-cultural variation between norms, values, and beliefs that affect the pursuit of reproductive fitness can be explained by the amount of time that has passed since the social networks in the population began to widen to become less kin-based.

-A substantial part of the cross-cultural variation in the extent to which people's beliefs are influenced by religious faith can also be largely explained by the amount of time that has passed since social networks became less kin-based. 
We could test these predictions if we knew when social networks began to widen in a variety of populations. But, although the evidence cited above strongly suggests that a dramatic widening of social networks occurs at the inception of modernization (e.g., Zelinsky 1971; Watkins 1990; Davis 1997 [1937]; Kohler 2001), the timing of social network change has not been systematically monitored.

We do, however, know the timing of a common point in what we suggest is a cultural evolutionary continuum that begins with the widening of social networks and the reduction of influence from kin. This common point is the adoption of family limitation. All populations experience a fertility decline after they have begun to develop economically. Because the birth rate of most populations has been recorded for many years, we can determine when members of a population began to limit family size. Knowing the year fertility began to decline (YFBD) in a country therefore allows us to assign countries to a position along the modernizing cultural continuum. We acknowledge that the association of YFBD with the change in social networks is itself a hypothesis. A definitive test of this would require detailed social histories from a reasonably large sample of societies in the early stage of modernization. But the proposed association is consistent with the social historical data cited above.

If position along the modernizing cultural continuum substantially explains cultural differences, then the timing of the onset of the fertility decline (YFBD) should, for a period of time, ${ }^{4}$ be highly correlated with measures that reflect the attitudes and behavior of different populations. The year fertility began to decline can be estimated for 174 countries (see Table 1). ${ }^{5}$ No substantial fertility decline has been detected in 13 of these countries, but the onset of their fertility decline has been projected (UNPD 2007). Countries whose fertility is projected to begin to decline in 2010 or earlier or (as in most cases) has already begun to decline are included in the analysis.

\section{Cross-national differences in attitudes}

To compare the extent to which members of a population are directed toward fitness-enhancement or adhere to beliefs arising from shared tradition rather than rational argument, we used two publicly available cross-national measures of attitudes and behavior: 1) the aforementioned World Values Survey, which has surveyed over a quarter of a million respondents in more than 75 countries since 1981 (see «http://www.worldvaluessurvey.org»); and 2) the Pew Global Attitudes Project, which surveyed over 38,000 people in 44 countries in 2002 (see «http://pewglobal.org»). These surveys included questions designed to elicit attitudes toward reproductive behavior and religious beliefs. Scholars have used the mean responses of survey participants to compare the cultural values of each country's population (Inglehart and Welzel 2005; Inglehart and Baker 2000; Pew Research Center 2003). 
TABLE 1 Year in which fertility is estimated to have begun to decline or is projected* to begin to decline in 174 countries

\begin{tabular}{|c|c|c|c|c|c|}
\hline Afghanistan & $2008^{*}$ & Cuba & 1920 & Kuwait & 1975 \\
\hline Albania & 1968 & Czech Republic & 1905 & Kyrgyzstan & 1970 \\
\hline Algeria & 1982 & Denmark & 1898 & Laos & 1992 \\
\hline Angola & $2010^{*}$ & Djibouti & 1995 & Latvia & 1890 \\
\hline Argentina & 1920 & Dominican Republic & 1968 & Lebanon & 1970 \\
\hline Armenia & 1968 & Ecuador & 1971 & Lesotho & 1985 \\
\hline Australia & 1891 & Egypt & 1968 & Liberia & $2018^{*}$ \\
\hline Austria & 1907 & El Salvador & 1972 & Libya & 1985 \\
\hline Azerbaijan & 1969 & Equatorial Guinea & $2020^{*}$ & Lithuania & 1910 \\
\hline Bahamas & 1968 & Eritrea & 1989 & Luxembourg & 1881 \\
\hline Bahrain & 1973 & Estonia & 1885 & Macedonia & 1935 \\
\hline Bangladesh & 1981 & Ethiopia & 2001 & Madagascar & 1994 \\
\hline Barbados & 1966 & Fiji & 1960 & Malawi & 1995 \\
\hline Belarus & 1920 & Finland & 1912 & Malaysia & 1965 \\
\hline Belgium & 1881 & France & 1827 & Maldives & 1991 \\
\hline Belize & 1982 & Gabon & 1996 & Mali & $2008^{*}$ \\
\hline Benin & 1998 & Gambia & 1991 & Malta & 1940 \\
\hline Bhutan & 1995 & Georgia & 1935 & Mauritania & 1998 \\
\hline Bolivia & 1978 & Germany & 1888 & Mauritius & 1963 \\
\hline \multirow{2}{*}{$\begin{array}{l}\text { Bosnia and } \\
\text { Herzegovina }\end{array}$} & \multirow[b]{2}{*}{1908} & Ghana & 1990 & Mexico & 1974 \\
\hline & & Greece & 1913 & Micronesia & 1980 \\
\hline Botswana & 1984 & Guatemala & 1978 & Moldova & 1925 \\
\hline Brazil & 1966 & Guinea & 1998 & Mongolia & 1978 \\
\hline Brunei Darussalam & 1965 & Guinea-Bissau & $2020^{*}$ & Morocco & 1975 \\
\hline Bulgaria & 1915 & Guyana & 1970 & Mozambique & 1995 \\
\hline Burkina Faso & 2000 & Haiti & 1974 & Myanmar & 1976 \\
\hline Burundi & $2020^{*}$ & Honduras & 1977 & Namibia & 1990 \\
\hline Cambodia & 1972 & Hungary & 1900 & Nepal & 1988 \\
\hline Cameroon & 1993 & Iceland & 1903 & Netherlands & 1897 \\
\hline Canada & 1890 & India & 1973 & New Zealand & 1900 \\
\hline Cape Verde & 1986 & Indonesia & 1972 & Nicaragua & 1974 \\
\hline \multirow{2}{*}{$\begin{array}{l}\text { Central African } \\
\text { Republic }\end{array}$} & \multirow[b]{2}{*}{1997} & Iran & 1985 & Niger & $2008^{*}$ \\
\hline & & Iraq & 1980 & Nigeria & 2000 \\
\hline Chad & $2015^{*}$ & Ireland & 1922 & Norway & 1903 \\
\hline Chile & 1966 & Italy & 1913 & Oman & 1990 \\
\hline China & 1969 & Ivory Coast & 1991 & Pakistan & 1991 \\
\hline Colombia & 1968 & Jamaica & 1971 & Panama & 1970 \\
\hline Comoros & 1991 & Japan & 1945 & Papua New Guinea & 1981 \\
\hline Congo & 2005 & Jordan & 1980 & Paraguay & 1969 \\
\hline \multirow{2}{*}{$\begin{array}{l}\text { Congo, Democratic } \\
\text { Republic }\end{array}$} & \multirow[b]{2}{*}{$2020^{*}$} & Kazakhstan & 1965 & Peru & 1971 \\
\hline & & Kenya & 1984 & Philippines & 1963 \\
\hline Costa Rica & 1963 & Korea (North) & 1972 & Poland & 1910 \\
\hline Croatia & 1908 & Korea (South) & 1962 & Portugal & 1916 \\
\hline
\end{tabular}


TABLE 1 (continued)

\begin{tabular}{llllll}
\hline Qatar & 1978 & Spain & 1920 & Tunisia & 1971 \\
Romania & 1905 & Sri Lanka & 1962 & Turkey & 1962 \\
Russian Federation & 1925 & St. Lucia & 1970 & Turkmenistan & 1975 \\
Rwanda & 1990 & St. Vincent and & & Uganda & $2012^{*}$ \\
Samoa & 1970 & Grenadines & 1965 & Ukraine & 1910 \\
São Tomé and & & Sudan & 1985 & United Arab & \\
$\quad$ Principe & 1985 & Suriname & 1970 & Emirates & 1975 \\
Saudi Arabia & 1985 & Swaziland & 1987 & United Kingdom & 1893 \\
Senegal & 1990 & Sweden & 1902 & United States & 1890 \\
Serbia and & & Switzerland & 1887 & Uruguay & 1920 \\
$\quad$ Montenegro & 1915 & Syria & 1985 & Uzbekistan & 1975 \\
Sierra Leone & $2020^{*}$ & Tajikistan & 1980 & Vanuatu & 1965 \\
Singapore & 1959 & Tanzania & 1990 & Venezuela & 1970 \\
Slovakia & 1905 & Thailand & 1966 & Vietnam & 1975 \\
Slovenia & 1905 & Togo & 1990 & Yemen & 1990 \\
Solomon Islands & 1984 & Tonga & 1967 & Zambia & 1985 \\
Somalia & $2010^{*}$ & Trinidad and & & Zimbabwe & 1976 \\
South Africa & 1965 & Tobago & 1966 & & \\
\hline
\end{tabular}

SOURCES: UNPD 2007; Coale and Watkins 1986; Caldwell and Ruzicka 1978; Palloni 2000; Tomasson 1977; Milne and Wright 1997; Coale and Treadway 1986; Ogawa and Retherford 1993.

To see how well YFBD explained the variance in attitudes between countries, we calculated the correlation coefficient (Pearson's $r$ ) between the year fertility began to decline in a country and the country mean of responses to relevant survey questions. For comparison, we also calculated the correlation coefficient between these means and an environmental variable (per capita GDP) that indicates the country's current economic development.

\section{Cross-national differences in behavior}

A number of cross-national measures and indexes indicate the prominence that members of the population give to the pursuit of genetic fitness:

-Total fertility rate (TFR)(UNPD 2007), the average number of children that would be born to a woman if she experienced the current age-specific fertility rates throughout her lifetime. This measure reflects the extent to which members of the population want and feel able to have children or grandchildren.

-Per capita gross domestic product (GDP)(World Bank 2006), the total market value of all final goods and services produced in a country during a year, divided by the midyear population. This, in part, reflects the extent to which members of the population are contributing to the national economy 
rather than enhancing their inclusive fitness by producing and raising children. Women's participation in education and the work force drives the GDP upward and the TFR downward.

- "Corruption perception index" (CPI) (Transparency International 2006), a measure of the perception of corruption in a country based on 16 polls and surveys from ten institutions. High levels of corruption (low CPI) suggest that people are more inclined to behave in ways likely to improve their inclusive fitness, such as helping their relatives and friends. Low levels of corruption (high CPI) suggest people are more likely to be loyal to such non-family institutions as the state, an employer, or a trading partner.

— "Gender empowerment measure" (GEM) (UNDP 2006), an indicator of the extent to which the power and influence of women in a country is the same as that of men. The United Nations Development Programme created this measure by combining inequalities in three areas: political participation and decisionmaking, economic participation and decisionmaking, and power over economic resources. A high GEM, which signifies greater gender equity, suggests that the social rewards associated with being a mother and housewife compare unfavorably with those associated with work outside the home. When social rewards for motherhood are low, women pursue the same goals as men rather than devote their effort to increasing their genetic fitness.

- Average number of years spent in education (UNESCO 2006). The more years children spend in school, the longer they remain dependent on their parents, the more expensive they are to raise, and the less efficient the conversion of resources to offspring. Children who attend school longer will also be more likely to postpone childbearing.

-Mean national IQ. Lynn and Vanhanen (2002) estimated what they argued was the mean IQ for the populations of 81 countries based on results of tests that had been administered in those countries. From these measurements they inferred the mean IQ for the populations of another 104 countries based on their proximity to countries where IQ had been measured. They reported correlations ranging from 0.5 to 0.7 between mean IQ of a population and its wealth as measured by per capita GDP. Lynn and Vanhanen's methods have been criticized, and their conclusion that wealth differentials at the population level can be partly explained by differences in the intelligence of the population has been disputed (e.g., Volken 2003). Nevertheless, their data have been used by others, and their results and conclusions have been widely cited to support innatist views of intelligence. It is therefore worthwhile to consider cultural explanations for the correlation that they observed between wealth and IQ.

A rise in IQ ranging from three to five points per decade has been observed in industrialized countries (Flynn 1984, 1987a, 1987b). This may be partly the result of parents no longer attempting to maximize reproductive 
success. Children from smaller families have been found to have higher IQs, as have first-born children and children who spend more time with their parents and other adults (Zajonc and Zajonc 1976; Steelman et al. 2002). A high average IQ suggests that a large proportion of the population has been raised by parents who invest substantially in a small number of children rather than produce a larger family and expect older children to look after younger ones. This effect will act as a synchronic environmental factor. Another explanation of IQ variation between countries is that IQ increases as people deal with ever more complex artifacts and social environments, one of the diachronic, historically cumulative products of modernization (Schooler 1998). Nisbett (2009) reviews the evidence that the amount and quality of schooling a young person receives as well as other aspects of culture result in large differences in IQ. He points out that the large estimates of heritability of IQ within some populations at the same point in time are perfectly consistent with large environmental and cultural effects on IQ across populations. The idea that modernization has caused large changes in IQ over time is also quite consistent with high estimated heritabilities within populations at the same point in time.

— "Sociosexual orientation inventory" (SOI) index, a questionnairederived measure of willingness to have casual sex, obtained from samples of mostly university undergraduates in over 40 countries (Schmitt 2005). A higher average SOI index in a country indicates that social sanctions discouraging casual sex are more relaxed. The population is more tolerant of behavior that might result in unwanted pregnancy, family disruption, or the spread of infection. This change in attitude toward recreational sex is more likely to be associated with the sexual behavior of females than of males. Females suffer fitness costs when pregnancy results from mating with an uncommitted partner, while males may gain in fitness. Traditional societies, therefore, are likely to have a "double standard," with sanctions against females having casual sex being stronger than sanctions against males.

There are problems associated with using data collected from university students, who are likely to come from higher socioeconomic sectors of the population. While this is true in all countries, the extent of the bias depends on the proportion of young people in the country who attend university. In countries that have begun to develop more recently, higher education is more likely to be the preserve of the elite, who have a wider range of social contacts and are more culturally modern. The SOI index in these countries is therefore likely to be less representative of the country-wide average than in countries that began to develop earlier. If, in spite of this bias, YFBD explains part of the variance in the female SOI index between countries, the finding would support the suggestion that maintaining traditional sexual norms become increasingly inconsistent with achieving reproductive success after a population has begun to develop. 


\section{Variables used in regression analyses}

Modernization involves many cultural and environmental changes occurring simultaneously, influencing one another and potentially masking one another's effects. Environmental factors such as wealth and health, and cultural variables such as religiosity, are often seen as contributing to cross-national differences in behavior. We carried out regression analyses to compare the effectiveness of these predictors of behavior with the historical variable YFBD.

We used four variables reflecting behavior as dependent variables: the corruption perception index, gender empowerment measure, average years spent in education, and the female sociosexual orientation index. We compared several independent variables: per capita GDP (as an indicator of wealth), health-adjusted life expectancy (as an indicator of health), the mean national response to the WVS question "How important is religion in your life?" (as an indicator of religiosity), and YFBD (as an indicator of historical social structure).

The correlation between mean national IQ and a country's per capita GDP has been used to support the proposal that some countries are wealthier because their population is more intelligent (Lynn and Vanhanen 2002). We carried out regression analyses to compare the effectiveness of YFBD, health-adjusted life expectancy, and mean national IQ as "predictors" of per capita GDP.

\section{Results}

\section{Cross-national differences in attitudes}

Consistent with the first prediction of the kin influence hypothesis, the year that fertility began to decline in a country is highly correlated with the national mean of attitude measures relating to sexual behavior, parenting behavior, and religious belief (see Table 2 ). The more recently fertility began to decline in a country, the more inclined its population is to believe that children should be obedient, unconditionally love and respect their parents, and want to make them proud. At the same time, they are less likely to approve of activities inconsistent with adults attending to the biologically essential job of producing and raising children. Divorce, prostitution, abortion, and homosexuality are less justifiable in the view of members of populations that have more recently begun to limit family size.

The correlation between ideal family size and YFBD is among the weakest. This is consistent with the prediction of the kin influence hypothesis about the process of cultural change that accompanies modernization (see Figure 1). The desire for a large family is abandoned relatively early in the modernization process. Thus, in this sample of countries that are developed 


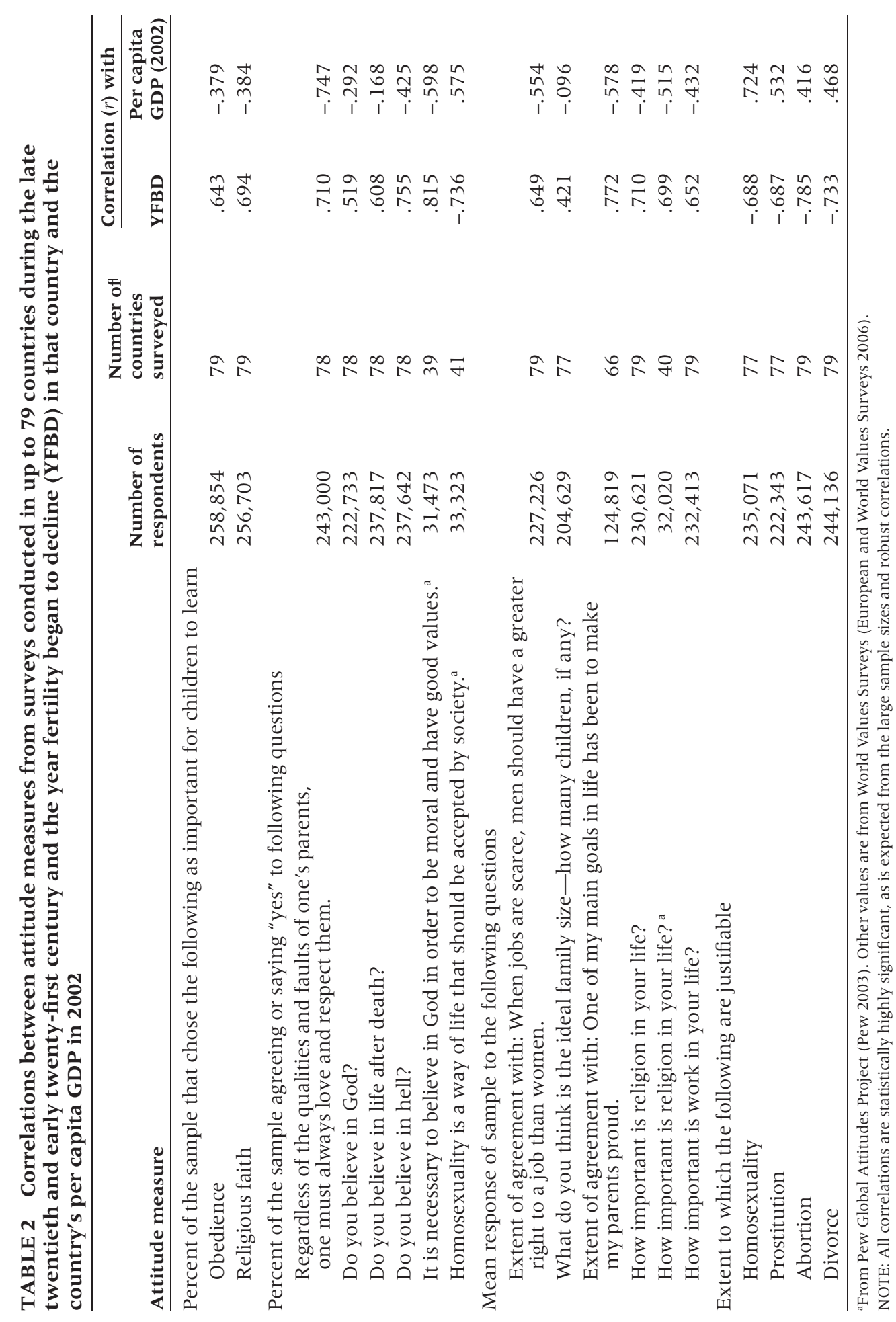


or have begun to develop, there is little variation between countries where fertility began to decline 30 years ago and those that began to modernize 130 years ago. Interestingly, in the countries where fertility began to decline earliest, the TFR is lower than the mean of ideal family size, whereas in countries where fertility began to decline recently, the TFR is greater than the mean ideal family size.

Consistent with the second prediction of the hypothesis, members of populations with a recent demographic transition are also more likely to subscribe to religious beliefs and want children to be raised with religious faith. The correlation is weaker between YFBD and belief in God and other responses related to religion. This is probably because many Eastern religions do not include a belief in God or because belief in "a god" is less explicit than in Judeo-Christian and Islamic traditions.

We also find significant correlations between the wealth of a country (GDP per capita) and the mean responses to many of the questions. This finding supports the argument that some aspects of parenting and sexual behavior are influenced by poverty and wealth but is also consistent with the argument that attitude change and rise in wealth are part of the same evolutionary process. With only two exceptions, the correlations between attitude measures and GDP per capita are weaker than those between attitude measures and YFBD.

\section{Cross-national differences in behavior}

Consistent with the first prediction of the kin influence hypothesis, indexes that reflect behavior influencing reproductive success are highly correlated with the year of onset of the fertility decline (see Table 3). As predicted, this includes female but not male willingness to have casual sex (SOI index). Some of the variables are also highly correlated with each other. This, too, is consistent with the prediction. If the behaviors are co-evolving, the variables that reflect them will be closely correlated.

Although correlations between YFBD and attitude and behavior variables are strong, YFBD does not explain more than 60 percent of the variance between countries and even less of the individual-level variance. A closer look at the relationship between the variables suggests explanations for more of the variance. We plotted the index of each country against the year fertility began to decline (or is projected to decline) in that country (Figures 2-8).

The decline in TFR appears to be close to linear for a generation or so after it begins, and then TFR ceases to decline after reaching European levels, with TFR slightly below replacement (Figure 2). This suggests that all countries that have begun to develop embark on the same cultural shift from a regime consistent with maximizing inclusive fitness to a regime that encourages the birth of some children but does not encourage reproduction 


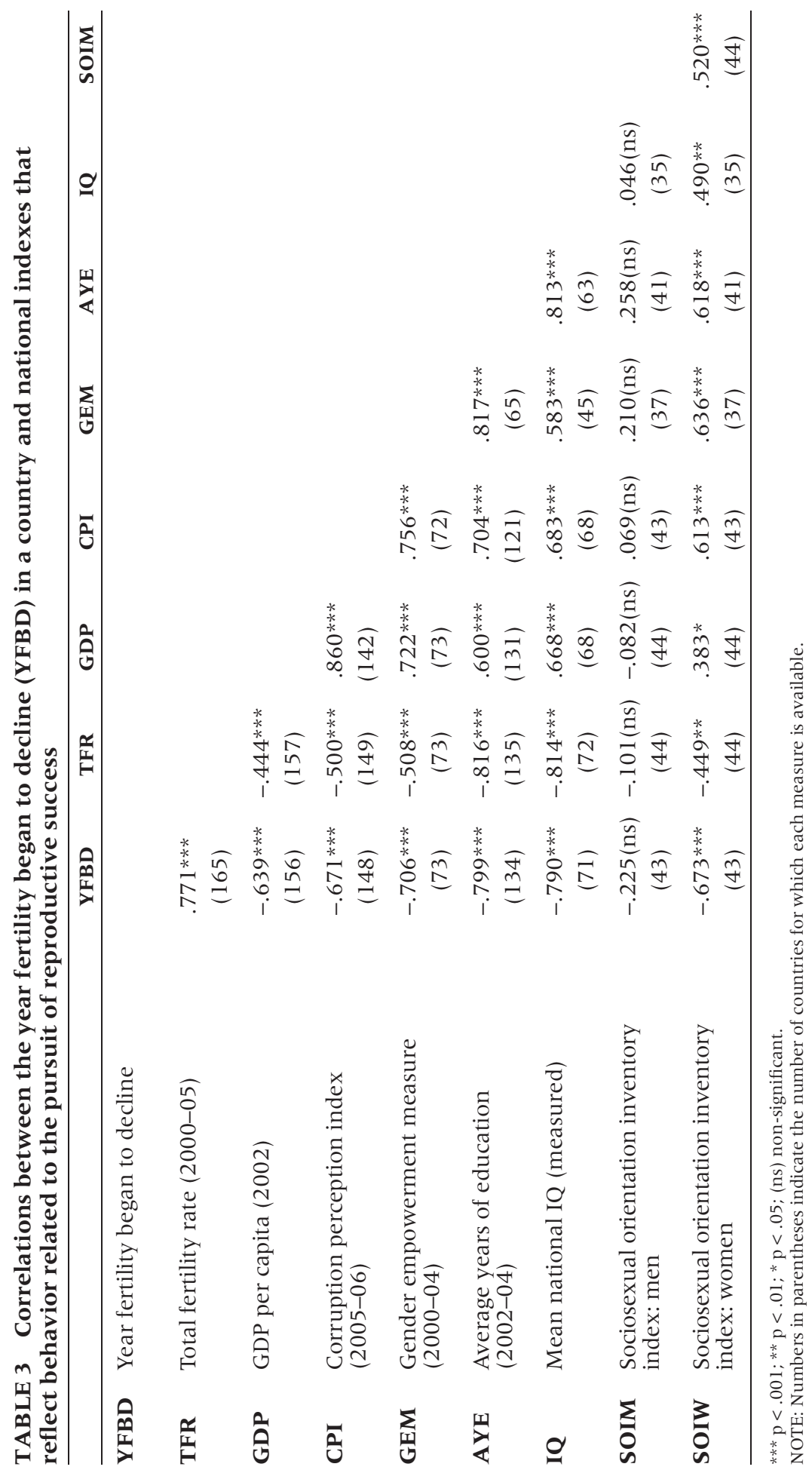


FIGURE 2 Relationship between total fertility rate in 2000-2005 (UNPD 2007) and the year fertility began to decline in 174 countries

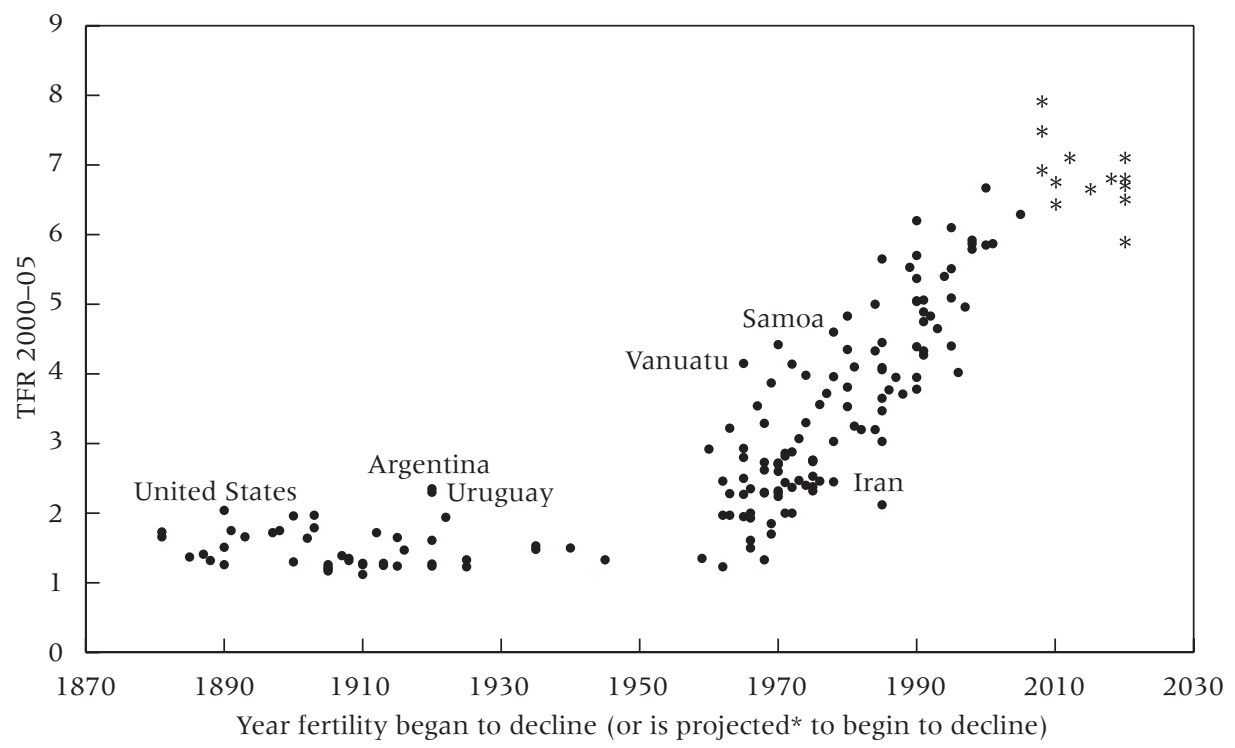

at fitness-optimizing levels. In European countries, TFR stabilized at between 2 and 3 births and then declined further after modern birth control technology became widely available. Since the development of modern birth control, TFR has tended to stabilize at below-replacement-level fertility.

As can be seen in Figure 3, the pattern of variation between countries gives information about other factors that play a role in explaining the differences between countries. As predicted by the kin influence hypothesis, per capita GDP rises with time since fertility began to decline. An examination of the outliers shows that the countries that are substantially wealthier than would be predicted by YFBD are oil-rich (shown as dark triangles). In such countries, GDP per capita is largely a windfall based on resource endowment that other countries value. In the standard development trajectory, GDP per capita increases with social modernization, which brings higher female participation in the paid labor force and fewer dependent children. Among the outliers that are poorer than predicted by the hypothesis are European states that belonged to or were associated with Comecon (dark circles). In these countries, traditional communities eroded as industrial means of production developed, but their GDP per capita advanced slowly compared to more capitalist economies because of the inefficiencies of centrally planned economies.

In countries where fertility has begun to decline more recently, public officials and politicians are more likely to be perceived to be abusing power and trust. YFBD explains about 45 percent of the variance between countries' 
FIGURE 3 Relationship between GDP per capita in 2002 (World Bank 2006) and the year fertility began to decline in 173 countries

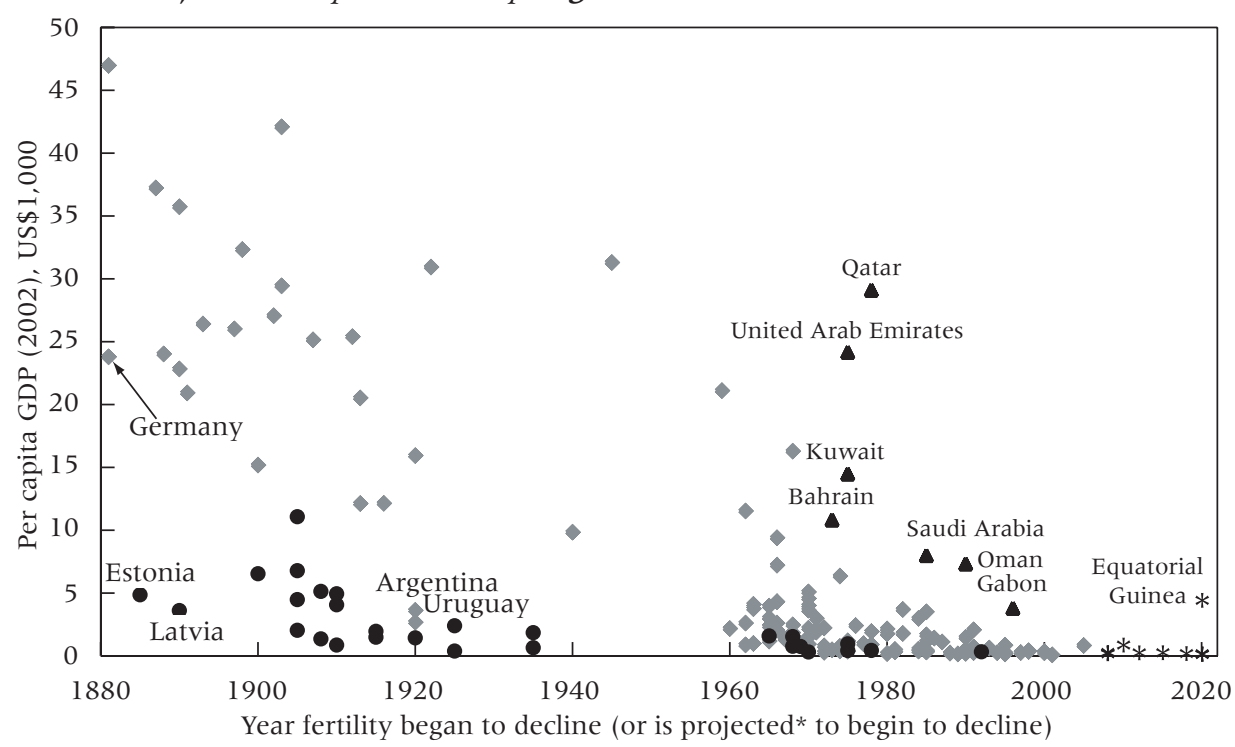

NOTE: Dots denote countries that had some history as centrally planned economies. Triangles denote oil-rich economies.

corruption perception index score (Figure 4). Former communist countries tended to be more corrupt than predicted by YFBD.

The gender empowerment measure increases with increasing time that has passed since fertility began to decline in a country. This supports the prediction that once women are producing fewer children their behavior continues to change as they increasingly compete with men to acquire wealth and power. YFBD explains about 50 percent of the variance between countries. In Nordic countries and the African countries with a matrilineal tradition, men and women tend to be more equal than predicted (Figure 5).

The countries that first experienced fertility decline appear to be approaching an upper limit on the number of years that young people spend in education (Figure 6), but it has become common in countries where fertility began to decline earliest for young people to stay in full-time education until they are in their 20s.

YFBD explains over 60 percent of variance in mean IQ score between countries, and the correlation is stronger than between IQ and GDP per capita. Unlike Lynn and Vanhanen (2002), we calculated the correlation using only mean national IQ values for the 71 countries where the data were based on measurement rather than extrapolation and where fertility had begun to decline. The countries that experienced fertility decline first may be approaching an upper limit of IQ (Figure 7). Indeed recent evidence suggests that the rise in IQ that has been observed in a number of coun- 
FIGURE 4 Relationship between corruption perception index for 2006 (Transparency International 2006) and the year fertility began to decline in 155 countries

[y-axis labels OK for Figs. 4 and 5?]

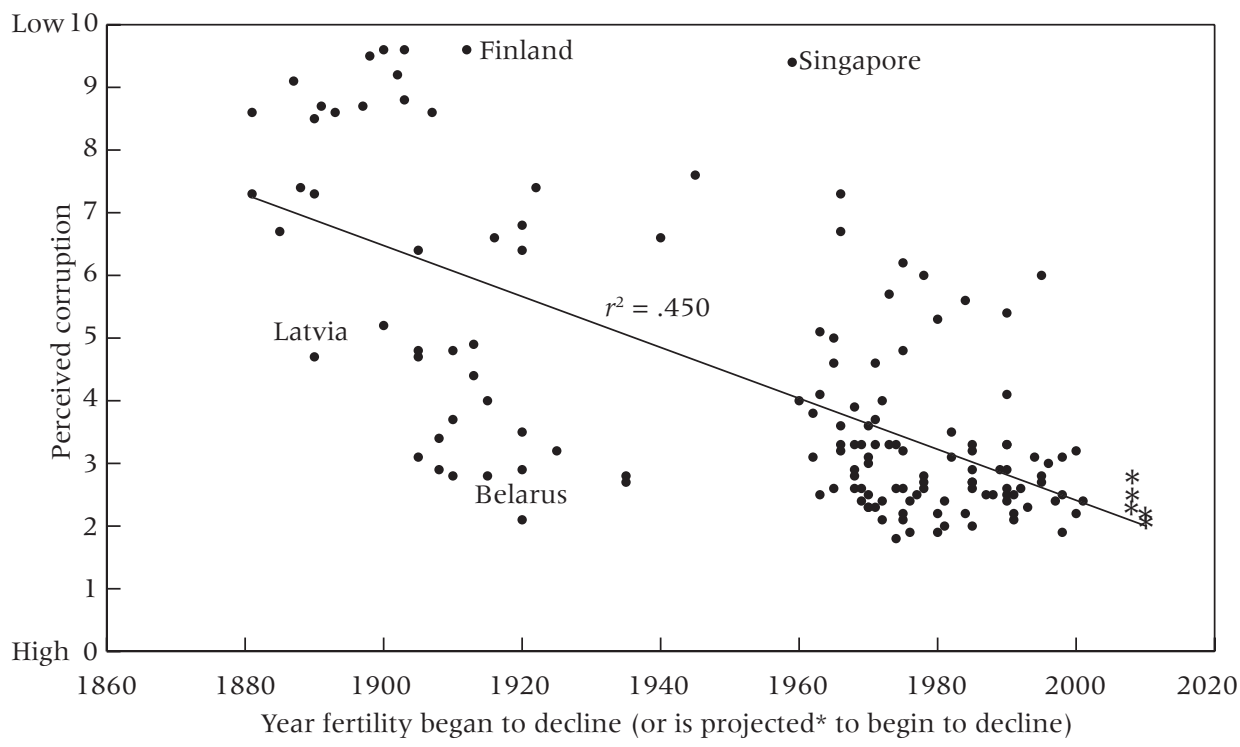

tries for most of the twentieth century (Flynn 1984, 1987a,b) may now be stabilizing (Sundet et al. 2004) or starting to decline (Teasdale and Owen 2005). In countries strongly influenced by Confucian culture (China, Japan,

FIGURE 5 Relationship between the gender empowerment measure for 2004 (UNDP 2006) and the year fertility began to decline in 73 countries

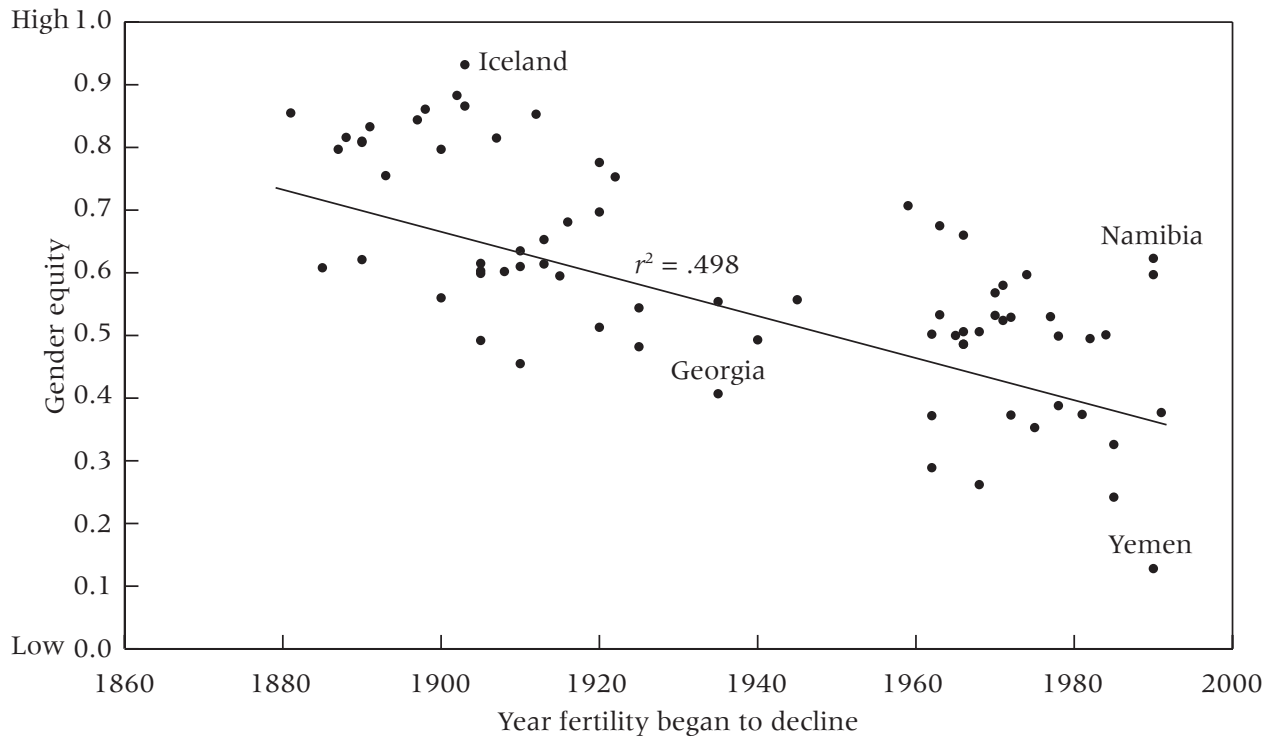


FIGURE 6 Relationship between average length of schooling for 2002-04 (UNESCO 2006) and the year fertility began to decline in 138 countries

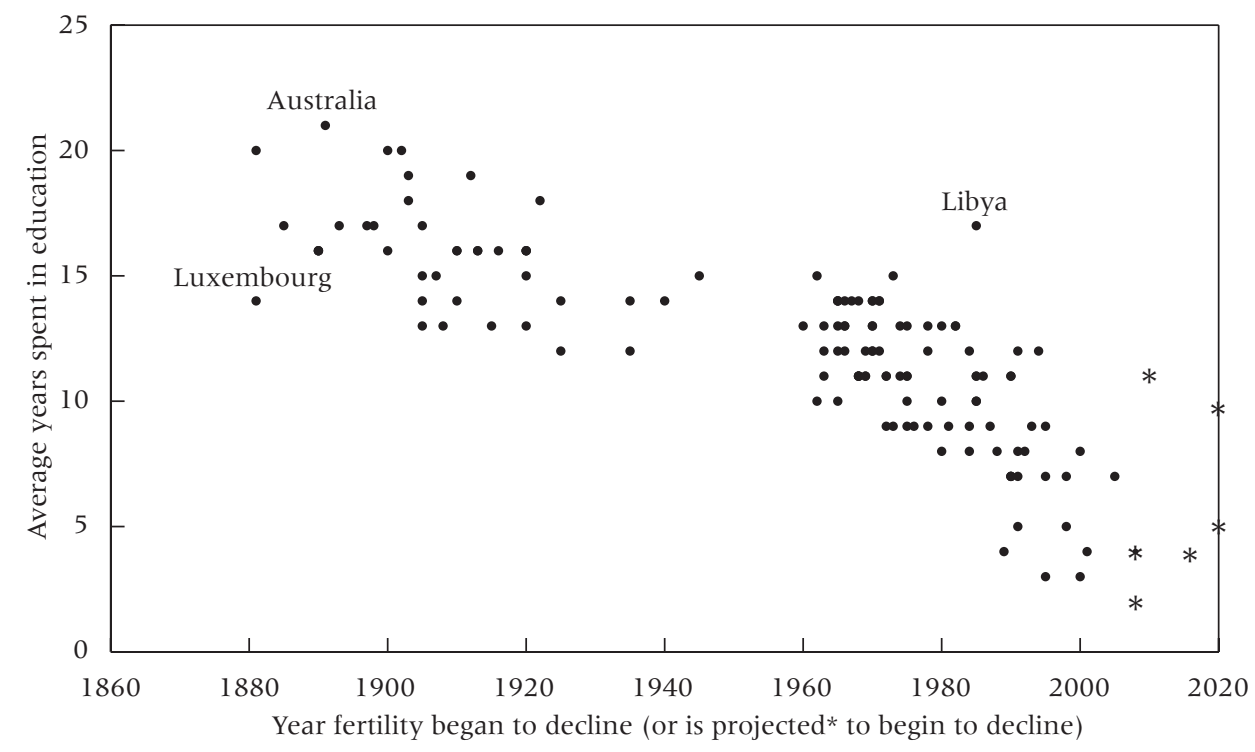

Korea, and Singapore), mean IQ is higher than predicted by YFBD. Genetic explanations have been proposed for this small difference in IQ (Lynn and Vanhanen 2002), but these countries also share a cultural heritage that includes high respect for schooling (Dandy and Nettelbeck 2002) and ide-

FIGURE 7 Relationship between mean national IQ (Lynn and Vanhanen 2002) and the year fertility began to decline in 75 countries

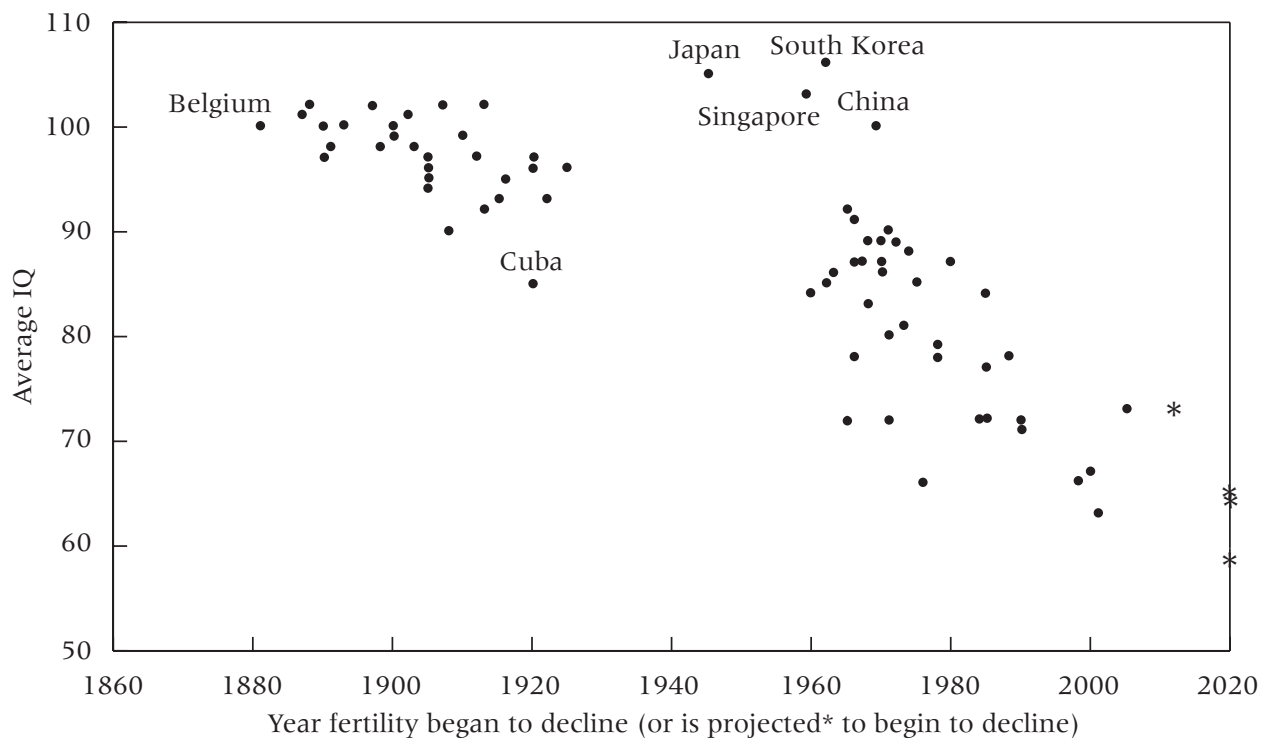


FIGURE 8 Relationship between the mean sociosexual orientation inventory index of young men and women measured circa 2002 (Schmitt 2005) and the year fertility began to decline in 43 countries

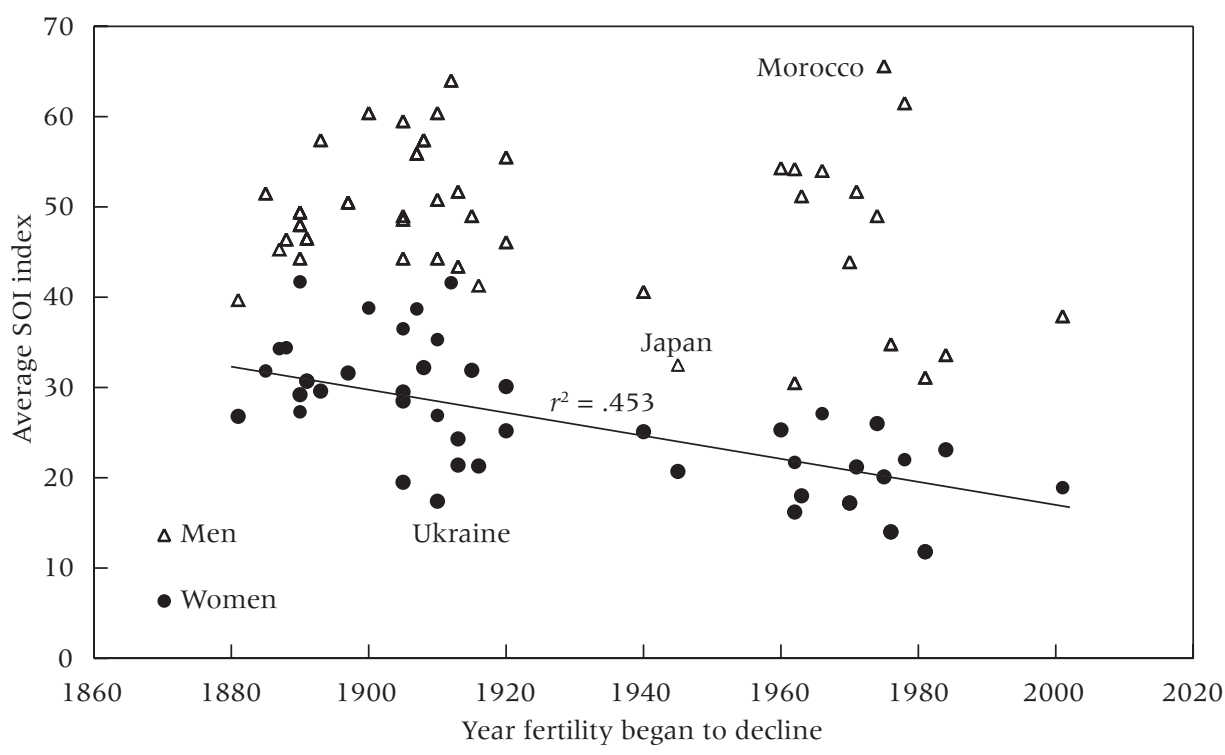

ographic written language, the learning of which might develop cognitive skills that increase IQ score.

As predicted by the kin influence hypothesis, the SOI index for a county's young women (but not its young men) is correlated with YFBD (Figure 8). Over 45 percent of the variance is explained by YFBD.

\section{Comparing correlated factors}

In three of the four indexes of behavior, those reflecting corruption, female equality, and education, over 60 percent of the variation between countries is explained by one other variable and YFBD (Table 4, panels a through c). YFBD on its own predicted over 40 percent of the variance in the mean female sociosexual orientation inventory (Table 4, panel d).

These regression models show that evidence of an association between an environmental variable, such as per capita GDP, and a cultural variable, such as religiosity, can appear to be an important predictor of behavior. But the amount of the variance the association explains is greatly reduced when the year fertility began to decline is included in the model. A country's per capita GDP remains a strong predictor of the corruption perception index (Table 4, panel a) and gender empowerment measure (Table 4, panel b), but this does not confirm that wealth is a cause of low corruption or high female equality. In fact, the direction of causation is more likely to be the 


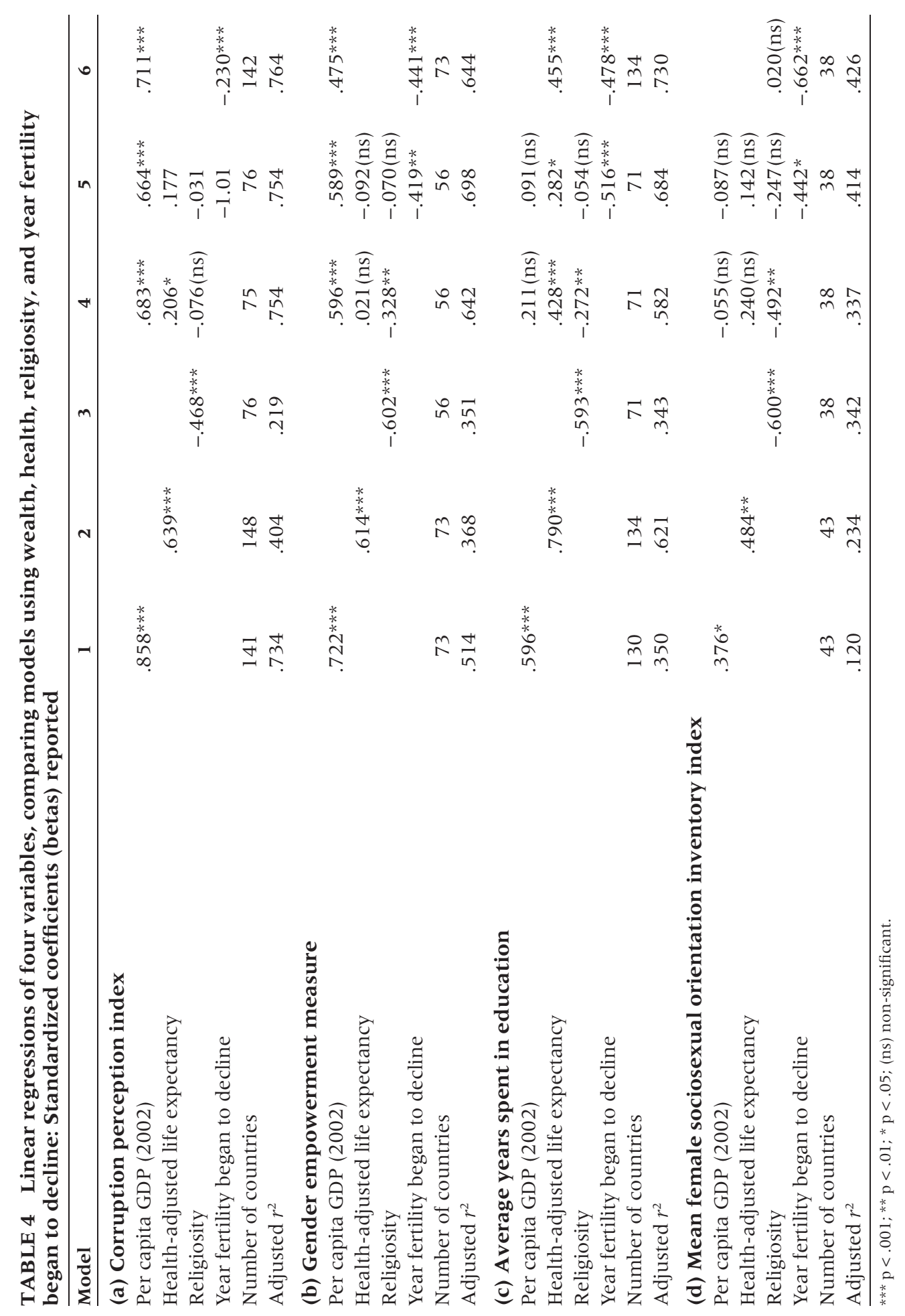


TABLE 5 Linear regression between per capita GDP and other variables (national IQ, health, and year fertility began to decline) in six models: Standardized coefficients (betas) reported

\begin{tabular}{llllccc}
\hline Model & $\mathbf{1}$ & $\mathbf{2}$ & $\mathbf{3}$ & $\mathbf{4}$ & $\mathbf{5}$ & $\mathbf{6}$ \\
\hline $\begin{array}{l}\text { Mean national IQ } \\
\text { Health-adjusted }\end{array}$ & $.665^{* * *}$ & & .256 & $.296^{*}$ & & $.065(\mathrm{~ns})$ \\
$\quad$ & & $.594^{* * *}$ & $.456^{*}$ & & $.272^{* *}$ & $.312(\mathrm{~ns})$ \\
$\quad \begin{array}{l}\text { Year fertility began to } \\
\quad \text { decline }\end{array}$ & & & & & & \\
Number of countries & 67 & 156 & 67 & 67 & 156 & 67 \\
Adjusted $r^{2}$ & .433 & .353 & .467 & .505 & .435 & .516 \\
\hline
\end{tabular}

*** $\mathrm{p}<.001 ; * * \mathrm{p}<.01 ; * \mathrm{p}<.05 ;$ (ns) non-significant.

other way. Countries are likely to be wealthier because they are less corrupt and more women are educated and contributing to the formal economy. By contrast, one cannot argue that the year fertility began to decline was influenced by the level of corruption or gender equality within a country many years later.

A strong correlation exists between mean national IQ and per capita GDP in the countries for which Lynn and Vanhanen (2002) estimated mean national IQ based on measurement rather than extrapolation (Table 5). Over 40 percent of the variance in GDP per capita is "explained" by IQ. But health-adjusted life expectancy "explains" nearly as much of the variance for a much larger sample of countries. When both variables are included in a regression model, the variable reflecting health proves to be more important than IQ. But the year fertility began to decline in the country is found to explain more of the variance between countries than health or IQ, considered separately or together. This is consistent with the proposal of the kin influence hypothesis that populations that have begun to modernize are proceeding along a cultural evolutionary process and that many of the differences between countries can be partly explained by the amount of time that has passed since they began to modernize.

\section{Discussion}

Data reflecting cross-national differences are consistent with the view that modernization is a process of cultural evolution triggered by the widening of social networks that occurs with economic development. A considerable number of variables across many cultures change in concert and do so in ways that the kin influence hypothesis predicts. In countries that began to undergo economic development later than populations of European descent, cultural change appears to be following the same course as Europeans experienced. The timing of the fertility decline (YFBD), an event that occurs in 
all countries that develop economically, is frequently the single best predictor of the current value of measures of attitudes and behavior. And it also frequently plays a large role in multiple models.

Social scientists have provided evidence to support synchronic or environmental explanations of cultural change and cultural differences. It makes sense that norms, values, and behavior should be sensitive to contemporaneous environmental factors. Correlations between combinations of variables that represent these factors have provided support for a variety of plausible models. We can therefore understand why many social scientists may question whether they need to consider the possibility that cultural change is part of a diachronic process that was set in motion by a historical event.

On the other hand, extensive investigation and discussion over many decades have failed to develop a consensus about the mechanisms of cultural change. Nor have social scientists developed models of cultural change in which the values of environmental variables generate reliable predictions about the course of future cultural change or policy-relevant advice on how such change might be managed. Coupling an environmental approach with an evolutionary explanation based on ill-defined notions about people being liberated from constraints has also failed to generate useful models that predict future change.

We therefore believe that the evolutionary approach outlined in this article broadens our understanding of why people become modern. The kin influence hypothesis suggests that cultural evolution is triggered by a widening of social networks. The findings reported here cannot prove this to be the trigger, but they are consistent with the trigger being the widening of social networks that occurs early in economic development. The formal model presented elsewhere, along with evidence of the way the content of social influence is likely to change as networks widen (Newson et al. 2007), provides a strong argument that the widening of social networks will initiate the cultural evolution and cultural differentiation that we have observed. If past changes in the structure of communities are responsible for cultural change years later, information about the social history of a population will help to predict future social change and may suggest ways that policymakers can influence its course.

In a statistical sense, the historical variable YFBD, or years since fertility began to decline, "explained" substantial amounts of the variance between countries. Moreover, it is possible to cite specific reasons for some of the unexplained variation, such as the early demographic transitions but relatively low per capita GDP of the countries that in the second part of the twentieth century were part of the Comecon. The explanatory power of YFBD is also reduced because of variations in the degree of heterogeneity within a country. The indexes and measures used in the analysis, including YFBD, are observed at the national level. A country in which some groups live in mod- 
ern communities while others live in isolated small-scale communities will appear to abandon traditional values more slowly than countries in which the switch to wider social networks occurs at roughly the same pace throughout. For a country like India, where a large diverse population inhabits a vast subcontinent, the change in social structure occurred more slowly than in a smaller, more homogeneous country like Thailand. We would expect, therefore, that the cultural changes characteristic of modernization will also occur more slowly in India. The United States also covers a large area with a heterogeneous population, and, although the American population is unquestionably modern, there is considerable divergence between the "social conservatives" and those whose values are closer to those of Europeans (Pew Global Attitudes Project 2003).

The amount of immigration a country has experienced also introduces variation in the speed of social change measured at the national level and may help to account for cultural differences between the United States and Europe. The sources of many immigrants to developed countries are countries with high fertility or fertility that was high until recently. The immigrants therefore bring less modern attitudes with them. It is notable that Japan, which modernized very rapidly, has permitted virtually no immigration. The large number of recent immigrants to the United States from Latin America as well as the continued isolation of some rural American communities may help to explain not only the higher fertility of the United States compared to Europe, but also a number of other cultural differences.

If the cultural change associated with modernization is characterized by new, less family-oriented cultural norms emerging from new, less family-oriented social networks, it is not surprising that foreign aid, foreign investment, or military intervention fails to modernize the attitudes of a population largely composed of people who were raised in villages. Forces from outside a population cannot make its members adopt modern ideas by installing a democratic government or by buying the country's natural resources. Providing schools and health centers may hasten the spread of modern ideas because they provide locations for social interaction between non-kin. But parents cannot be made to want to send their children to school if the parents believe that children should continue traditions by learning from older family members.

If modernizing populations are on the same cultural continuum, many of the differences in beliefs and values that divide countries must be viewed as temporary. Consider Iran and Britain. Fertility began to decline in Iran about 24 years ago, placing it at an early point in the continuum compared to Britain, where fertility began to decline in about 1893. When Britain was at the same point as contemporary Iran (24 years after 1893 was 1917), it 
was culturally very different from the Britain of today. Britain was fighting a bloody war with other European countries, and each country's army was blessed and encouraged by their religious leaders. While British men were sacrificing their lives in battle, British women were expected to dress modestly and were not allowed the vote until 1918. Iran today is far from identical to Britain in 1917, but if we are correct, the similarities of religiosity, nationalism, and gender norms in the two countries compared nearly a century apart are not coincidental. If modernization is an evolutionary process, time is a very important variable in explaining the differences and similarities between nations.

\section{Notes}

This research was supported by grants from the US National Science Foundation (grant number BCS-0455009) and by the UK Economic and Social Research Council (grant number RES-000-22-1261).

1 Some readers will interpret terms like "reproductive success" and "modernization" as value-laden terms. We mean to imply no value judgments about reproduction and modernity or the lack thereof. We aim to describe how phenomena related to these concepts work and not to draw value judgments.

2 If the fitness of an individual is determined by the number of copies of his or her genes that are present in future generations, the term "inclusive fitness" acknowledges that an individual's fitness is also enhanced by actions that promote the survival and reproduction of close relatives with whom he or she shares many genes.

3 We recognize, of course, that actual trajectories of modernization in particular societies are complex, and we point out some obvious signs of other processes in the data we use to test the hypothesis.

4 When equilibria are disturbed in evolutionary systems, the resulting change processes are curvilinear not linear and will eventually approach new equilibria. The change in parameters is close to linear in the early to middle phases, however, and it is for this reason that we predict correlations will exist. The relationship between YFBD and cultural change cannot be extrapolated far into the future, of course, especially for countries that underwent early fertility transitions. These societies have in effect entered uncharted territory. If fertility in all countries plunges below replacement and remains there, modern populations may be replaced by Anabaptists and similar groups that maintain pre-modern social institutions. Such a scenario neglects many other current trends, and even the most sophisticated scenario could not take account of many important uncertainties. The contrast between modern below-replacement fertility and the continuing high fertility of a few traditional societies that have successfully resisted the demographic transition surely means that substantial cultural changes will occur over the next few generations. The future, whatever it is, will be substantially different from the present.

5 Israel, Palestine, and Cyprus were excluded because the population of these countries includes a high proportion of recent immigrants or refugees. France was also excluded. Fertility began to decline in some parts of France in the first half of the nineteenth century. If this date were used, France would be a considerable outlier in any analysis. Theories for why France experienced such an early fertility decline were alluded to above. 


\section{References}

Alexander, R. D. 1979. Darwinism and Human Affairs. Seattle: University of Washington Press.

Apostolou, M. 2007. "Sexual selection under parental choice: The role of parents in the evolution of human mating," Evolution and Human Behavior 28: 403-409.

Avery, A., J. Chase, L. Johansson, S. Litvak, D. Montero, and M. Wydra. 2007. “America's changing attitudes toward homosexuality, civil unions, and same-gender marriage: 1977-2004," Social Work 52: 71-79.

Axinn, W. G. and J. S. Barber. 2001. "Mass education and fertility transition," American Sociological Review 66(4): 481-505.

Axinn, W. G. and S. T. Yabiku. 2001. "Social change, the social organization of families, and fertility limitation," American Journal of Sociology 105(5): 1219-1261.

Barber, J. S., L. D. Pearce, I. Chaudhury, and S. Gurung. 2002. "Voluntary associations and fertility limitation," Social Forces 80: 1369-1401.

Becker, G. 1960. "An economic analysis of fertility," in National Bureau of Economic Research (ed.), Demographic and Economic Change in Developed Countries. Princeton: Princeton University Press.

Behrman, J. R., H. P. Kohler, and S. C. Watkins. 2002. "Social networks and changes in contraceptive use over time: Evidence from a longitudinal study in rural Kenya," Demography 39: 713-738.

Bledsoe, C., A. Hill, U. D’Alessandro, and P. Langerock. 1994. “Constructing natural fertility: The use of Western contraceptive technologies in rural Gambia," Population and Development Review 20: 81-113.

Bongaarts, J. 2001. "Fertility and reproductive preferences in post-transitional societies," Population and Development Review 27(Supp.): 260-281.

Bongaarts, J. and S. C. Watkins. 1996. "Social interactions and contemporary fertility transitions," Population and Development Review 22: 639-682.

Borgerhoff-Mulder, M. 1988. "Behavioral ecology in traditional societies," TREE, 3: 260-264.

Boyd, R. and P. J. Richerson. 1985. Culture and the Evolutionary Process. Chicago: University of Chicago Press.

Brown, D. E. 1991. Human Universals. Philadelphia: Temple University Press.

Brown, J. 1970. "A note on the division of labor by sex," American Anthropologist, 34: 10731078.

Bumpass, L. and H. Lu. 2000. "Trends in cohabitation and implications for children's family contexts in the United States," Population Studies 54: 29-41.

Buss, D. M., T. K. Shackelford, L. A. Kirkpatrick, and R. J. Larson. 2001. "A half century of mate preferences: The cultural evolution of values," Journal of Marriage and the Family 63: 491-503.

Caldwell, J. C. and L. T. Ruzicka. 1978. "Australian fertility transition: An analysis," Population and Development Review 4: 81-103.

Chagnon, N. A. 1988. "Life histories, blood revenge, and warfare in a tribal population," Science 239: 985-992.

Coale, A. J. and R. Treadway. 1986. “A summary of the changing distribution of overall fertility, marital fertility, and the proportion married in the provinces of Europe," in A. J. Coale and S. C. Watkins (eds.), The Decline of Fertility in Europe. Princeton: Princeton University Press.

Coale, A. J. and S. C. Watkins. 1986. The Decline of Fertility in Europe. Princeton: Princeton University Press.

Cressy, D. 1986. "Kinship and kin interaction in early modern England," Past and Present 113 : 38-69.

Cronk, L. 1989. "Low socioeconomic status and female-biased parental investment: The Mukogodo example," American Anthropologist 91: 414-429. . 1991. "Human behavioral ecology," Annual Review of Anthropology 20: 25-53. 
Dandy, J. and T. Nettelbeck. 2002. “The relationship between IQ, homework, aspirations and academic achievement for Chinese, Vietnamese and Anglo-Celtic Australian school children," Educational Psychology 22: 267-275.

Darwin, C. 1859. On the Origin of Species by Means of Natural Selection, or, The Preservation of Favoured Races in the Struggle for Life. London: John Murray.

Davis, K. 1937. "Reproductive institutions and the pressure for population," Sociological Review 7: 289-306.

- 1997 [1937]. “Kingsley Davis on reproductive institutions and the pressure for population," Population and Development Review 23: 611-624.

Durkheim, E. 1984 [1893]. The Division of Labour in Society. Basingstoke: Macmillan.

Edgerton, R. B. 1992. Sick Societies: Challenging the Myth of Primitive Harmony. New York: Free Press.

Eisenstadt, S. N. (ed.) 2002. Multiple Modernities. New Brunswick, NJ: Transaction Publishers.

Espenshade, T. 1979. "The economic consequences of divorce," Journal of Marriage and the Family 41: 615-625.

European and World Values Surveys. 2006. “Four-wave Integrated Data File 1981-2004 v20060423," European Values Study Foundation and World Values Survey Association.

Festinger, L., S. Schachter, and K. Back. 1950. Social Pressures in Informal Groups: A Study of a Housing Community. New York: Harper.

Flynn, J. R. 1984. “The mean IQ of Americans: Massive gains 1932-1978," Psychological Bulletin 95: 29-51.

1987a. “Causal factors in generational IQ gains," Nature 328: 765.

- 1987b. "Massive IQ gains in 14 nations: What IQ tests really measure," Psychological Bulletin 101: 171-191.

Foley, R. A. 1996. "The adaptive legacy of human evolution: A search for the environment of evolutionary adaptedness," Evolutionary Anthropology 4: 194-203.

Greksa, L. 2002. "Population growth and fertility patterns in an Old Order Amish settlement," Annals of Human Biology 29: 192-201.

Hajnal, J. 1982. "Two kinds of preindustrial household formation system," Population and Development Review 8: 449-494.

Hamilton, W. D. 1964. "Genetic evolution of social behavior I, II," Journal of Theoretical Biology 7: $1-52$.

Hill, K. and A. M. Hurtado. 1996. Ache Life History: The Ecology and Demography of a Foraging People. New York: Aldine de Gruyter.

Hill, K. and H. Kaplan. 1988. "Tradeoffs in male and female reproductive strategies among the Ache: Part 1 and 2," in L. Betzig, M. Borgerhoff Mulder, and P. Turke (eds.), Human Reproductive Behavior: A Darwinian Perspective. New York: Cambridge University Press.

Hout, M., A. M. Greeley, and M. J. Wilde. 2001. "The demographic imperative in religious change in the United States," American Journal of Sociology 107: 468-486.

Hovland, C. I., I. L. Janis, and H. H. Kelly. 1953. Communication and Persuasion: Psychological Studies of Opinion Change. New Haven: Yale University Press.

Hrdy, S. B. 1999. Mother Nature: A History of Mothers, Infants and Natural Selection. Pantheon/Chatto \& Windus.

- 2007. "Evolutionary context of human development: The cooperative breeding model," in C. Carter, L. Ahnert, K. E. Grossmann, S. B. Hrdy, M. E. Lamb, S. W. Porges, and N. Sachser (eds.), Attachment and Bonding: A New Synthesis. Cambridge, MA: MIT Press.

Hurtado, A. M., K. Hawkes, H. Kaplan, and I. Hurtado. 1992. "Tradeoffs between female food acquisition and child care among Hiwi and Ache foragers," Human Nature 3: 185-2 16.

Inglehart, R. and W. E. Baker. 2000. "Modernization, cultural change, and the persistence of traditional values," American Sociological Review 65: 19-51.

Inglehart, R. and C. Welzel. 2005. Modernization, Cultural Change, and Democracy: The Human Development Sequence. New York: Cambridge University Press. 
Inkeles, A. and D. H. Smith. 1974. Becoming Modern: Individual Change in Six Developing Countries. Cambridge, MA: Harvard University Press.

Irons, W. 1979. "Cultural and biological success," in N. A. Chagnon, and W. Irons (eds.), Evolutionary Biology and Human Social Behavior. North Scituate, MA: Duxbury Press.

Knauft, B. M. 1987. "Divergence between cultural success and reproductive fitness in preindustrial cities," Current Anthropology 2: 94-1 14.

Kohler, H. P. 2001 . Fertility and Social Interactions. Oxford: Oxford University Press.

Kraybill, D. B. and M. A. Olshan. 1994. The Amish Struggle with Modernity. Hanover, NH: University Press of New England.

Lesthaeghe, R. 1983. “A century of demographic change in Western Europe: An exploration of underlying dimensions," Population and Development Review 9: 41 1-435.

Livi-Bacci, M. 1986. "Social group forerunners of fertility control in Europe," in A. J. Coale and S. C. Watkins (eds.), The Decline of Fertility in Europe. Princeton: Princeton University Press.

Low, B. S. 1993. "Ecological demography: A synthetic focus in evolutionary anthropology," Evolutionary Anthropology 1: 177-187.

. 1999. "Sex, wealth and fertility: Old rules in new environments," in L. Cronk, N. A. Chagnon, and W. Irons (eds.), Human Behavior and Adaptations: An Anthropological Perspective. New York: Aldine de Gruyter.

- 2000. Why Sex Matters. Princeton: Princeton University Press.

Lumsden, C. J. and E. O. Wilson. 1981. Genes, Mind, and Culture: The Coevolutionary Process. Cambridge, MA: Harvard University Press.

Lynn, R. and T. Vanhanen. 2002. IQ and the Wealth of Nations. Westport, CT: Praeger Publishers/Greenwood Publishing Group.

Mace, R. 1998. "The co-evolution of human fertility and wealth inheritance," Philosophical Transactions of the Royal Society B 353: 389-397.

Milne, R. G. and R. E. Wright. 1997. "The decline of fertility in Malta: The role of family planning," European Journal of Population 13: 147-167.

Murdock, G. P. 1967. “Ethnographic atlas: A summary," Ethnology 6: 109-236.

Nisbett, D. 2009. Intelligence and How to Get It. New York: W. W. Norton \& Co.

Newson, L., T. Postmes, S. E. G. Lea, and P. Webley. 2005. “Why are modern families small? Toward an evolutionary and cultural explanation for the demographic transition," Personality and Social Psychology Review 9: 360-375.

Newson, L., T. Postmes, S. E. G. Lea, P. Webley, P. J. Richerson, and R. Mcelreath. 2007. "Influences on communication about reproduction: The cultural evolution of low fertility," Evolution and Human Behavior 28: 199-210.

Ogawa, N. and R. D. Retherford. 1993. “The resumption of fertility decline in Japan: 1973-92," Population and Development Review 19: 703-741.

Ogburn, W. F. and M. F. Nimkoff. 1955. Technology and the Changing Family. Boston: Houghton Mifflin.

Palloni, A. 2000. "Fertility and mortality decline in Latin America," Annals of the American Academy of Political and Social Sciences 510: 126-144.

Parkin, T. 1992. Demography and Roman Society. Baltimore: Johns Hopkins University Press.

Petty, R. E. and J. T. Cacioppo. 1986. "The elaboration likelihood model of persuasion," in L. Berkowitz (ed.), Advances in Experimental Social Psychology. New York: Academic Press.

Pew Global Attitudes Project. 2003. "Views of a changing world: Summer 2002 44-nation survey," Pew Research Center

Pew Research Center. 2003. "Views of a Changing World 2003," The Pew Research Center for the People and the Press.

Postmes, T., R. Spears, and S. Cihangir. 2001. "Quality of decision making and group norms," Journal of Personality and Social Psychology 80: 918-930.

Postmes, T., R. Spears, and M. Lea. 2000. "The formation of group norms in computer-mediated communication," Human Communication Research 26: 341-371.

Richerson, P. J. and R. Boyd. 1984. "Natural selection and culture," Bioscience 34: 430-434. 
1999. "Complex societies: The evolutionary origins of a crude superorganism," Human Nature-An Interdisciplinary Biosocial Perspective 10: 253-289.

. 2001. "The evolution of subjective commitment to groups: A tribal instincts hypothesis," in R. M. Nesse (ed.), The Evolution of Commitment. New York: Russell Sage Foundation.

Schmitt, D. P. 2005. "Sociosexuality from Argentina to Zimbabwe: A 48-nation study of sex, culture, and strategies of human mating," Behavioral and Brain Sciences 28: 247-311.

Schooler, C. 1998. "Environmental complexity and the Flynn effect," in U. Neisser (ed.), The Rising Curve. Washington, DC: American Psychological Association.

Sherif, M. 1935. "A study of some social factors in perception: Chapter 4," Archives of Psychology 27(187): 1-60.

Sherif, M. and G. Murphy. 1936. The Psychology of Social Norms. New York and London: Harper \& Brothers.

Smith, R. M. 1981. "Fertility, economy, and household formation in England over three centuries," Population and Development Review 7(4): 595-622.

Steelman, L. C., B. Powell, R. Werum, and S. Carter. 2002. "Reconsidering the effects of sibling configuration: Recent advances and challenges," Annual Review of Sociology 28: 243-269.

Sternberg, R. J. 2004. "Culture and intelligence," American Psychologist 59: 325-338.

Sundet, J. M., D. G. Barlaug, and T. M. Torjussen. 2004. "A study of secular trends in mean intelligence test scores of Norwegian conscripts during half a century," Intelligence 32: 349-362.

Teasdale, T. W. and D. R. Owen. 2005. “A long-term rise and recent decline in intelligence test performance: The Flynn effect in reverse," Personality and Individual Differences 39: $837-843$.

Thornton, A., D. Alwin, and D. Camburn. 1983. "Causes and consequences of sex-role attitudes and attitude change," American Sociological Review 48: 211-227.

Tomasson, R. F. 1977. "A millennium of misery: The demography of the Icelanders," Population Studies 31: 405-427.

Tönnies, F. 1957 [1887]. Gemeinschaft und Gesellschaft (Community and Society). Leipzig: Fues's Verlag.

Transparency International. 2006. Corruption Perceptions Index.

Trinder, B. 2000. The Industrial Revolution in Shropshire. London: Phillimore.

Turner, J. 1991. Social Influence. Milton Keynes Open University Press.

Turner, J. C. 1982. "Towards a cognitive redefinition of the group," in H. Tajfel (ed.), Social Identity and Intergroup Relations. Cambridge: Cambridge University Press.

Turner, J. C., M. A. Hogg, P. J. Oakes, S. Reicher, and M. S. Wetherell. 1987. Rediscovering the Social Group: A Self-categorisation Theory. Oxford: Basil Blackwell.

UNESCO. 2006. World Education Indicators. Paris Institute for Statistics.

United Nations Development Programme (UNDP). 2006. Human Development Report 2006. New York: UNDP.

United Nations Population Division (UNPD). 2007. World Populations Prospects: The 2006 Revision Database. "http://ea.un.org/unpp».

Valente, T. W., S. C. Watkins, M. N. Jato, A. Vanderstraten, and L. P. M. Tsitsol. 1997. “Social network associations with contraceptive use among Cameroonian women in voluntary associations," Social Science $\theta$ Medicine 45: 677-687.

Vining, D. R., Jr. 1986. "Social versus reproductive success: The central theoretical problem of human sociobiology," Behavioral and Brain Sciences 9: 167-216.

Volken, T. 2003. "IQ and the wealth of nations: A critique of Richard Lynn and Tatu Vanhanen's recent book," European Sociological Review 19: 411-412.

Wang, F., J. Lee, and C. Campbell. 1995. "Marital fertility control among the Qing nobility: Implications for two types of preventive checks," Population Studies 49: 383-400.

Watkins, S. C. 1990. "From local to national communities: The transformation of demographic regimes in Western Europe, 1870-1960," Population and Development Review 16: 241-272. 
Watkins, S. C. and A. D. Danzi. 1995. “Women's gossip and social change: Childbirth and fertility-control among Italian and Jewish women in the United States, 1920-1940," Gender e Society 9: 469-490.

Weber, M. 2001 [1930]. The Protestant Ethic and the Spirit of Capitalism. London: Routledge Classics.

1951. The Religion of China: Confucianism and Taoism. Glencoe, IL: The Free Press.

Welzel, C. 2006. "A human development view on value change trends (1981-2006)," "http:// www.worldvaluessurvey.org/».

Wolfe, T. 1965. The Kandy-Kolored Tangerine-Flake Streamline Baby. New York: Farrar Straus and Giroux.

World Bank 2006. 2006 World Development Indicators. Washington, DC: The World Bank.

Zajonc, R. 1976. "Family configuration and intelligence," Science 192(4236): 227-236.

Zelinsky, W. 1971. "The hypothesis of the mobility transition," The Geographical Review 61: 219-249. 


\title{
Why Do People Become Modern? A Darwinian Explanation
}

\author{
LESLEY NEWSON \\ PETER J. RICHERSON
}

A procession of cultural changes, often referred to as "modernization," is initiated as a society undergoes economic development. But cultural change continues to be rapid in societies that industrialized several generations ago. Much of the change in both developed and developing societies is a progressive abandonment of the norms, values and beliefs that encourage behavior consistent with the pursuit of genetic fitness. The kin influence hypothesis suggests that these changes are part of a cultural evolutionary process initiated by the replacement of largely kin-based communities with social groups consisting largely of non-kin. Kin have an interest in encouraging each other to behave in ways consistent with the pursuit of reproductive success and a high level of social exchange between kin will tend to maintain norms that prescribe such behaviors. When social exchange between kin is reduced, these norms begin to relax. Cross-national comparisons of measures that reflect attitude and behavior support the hypothesis by showing that cultural differences between countries can be substantially explained by their position on a cultural continuum that begins with social networks widening so that they become less kin-based.

LESLEY NEWSON is Research Associate, Department of Environmental Science and Policy, University of California, Davis; and Research Fellow, School of Psychology, University of Exeter.

Peter J. Richerson is Distinguished Professor, Department of Environmental Science and Policy, University of California, Davis. 